\title{
Recognizing Women Leaders in Fire Science
}

\author{
Alistair M. S. Smith ${ }^{1, *}$ (i) , Crystal A. Kolden ${ }^{1}$ (i), Susan J. Prichard ${ }^{2}$, Robert W. Gray ${ }^{3}$, \\ Paul F. Hessburg ${ }^{4}$ and Jennifer K. Balch ${ }^{5}$ \\ 1 Department of Forest, Rangeland, and Fire Sciences, College of Natural Resources, University of Idaho, \\ Moscow, ID 83844, USA; ckolden@uidaho.edu \\ 2 Fire and Environmental Research Applications Team, United States Forest Service Pacific Northwest \\ Research Station, Seattle, WA 98103, USA; sprich@uw.edu \\ 3 R.W. Gray Consulting Ltd., Chilliwack, BC V2R 2N2, Canada; bobgray@shaw.ca \\ 4 Landscape and Climate Interactions Team $\beta$, USDA-FS, PNW Research Station-Forestry Sciences \\ Laboratory \& University of Washington, Wenatchee, WA 98801, USA; phessburg@fs.fed.us or \\ pfhess@u.washington.edu \\ 5 Department of Geography, University of Colorado-Boulder, Boulder, CO 80309, USA; \\ jennifer.balch@colorado.edu \\ * Correspondence: alistair@uidaho.edu
}

Received: 8 August 2018; Accepted: 16 August 2018; Published: 20 August 2018

\begin{abstract}
Across the breadth of fire science disciplines, women are leaders in fire research and development. We want to acknowledge some of these leaders to promote diversity across our disciplines. In Fire, we are also happy to announce a new Special Collection, through which we will continue to acknowledge current and future Diversity Leaders in Fire Science by inviting contributions from the leaders in this editorial, among others.
\end{abstract}

Keywords: leadership; women in science

\section{The Need to Recognize Women Leaders in Fire Science}

In 1965, Alice Rossi asked a fundamental question: "Why so few women in science?" [1]. It has long been recognized that women are underrepresented in science, technology, engineering, and mathematical (STEM) disciplines, with a substantial dialogue in the literature as to the impacts of such underrepresentation. As representation has increased, the debate now focuses on additional questions of equity in leadership, funding, advancement, and mechanisms of support for female scientists. These questions are embedded in three foundational concepts: (1) all scientists, regardless of gender, deserve equal access to opportunities; (2) the smartest and most talented people (regardless of gender) should be conducting scientific research, such that the most critical breakthroughs and contributions are realized; and (3) to understand and solve complex fire science problems, a broad diversity of perspectives, modes of problem attack, and epistemologies are needed [2]. We also acknowledge the need to recognize other underrepresented voices in the fire science community, such as indigenous and racial minorities, individuals with disabilities, and the LGBTQIA community, who all bring different ways of doing and knowing to science.

The reader may understandably ask: Why this journal? In fire science, there is a distinct and critical need to increase the recognition of women. Natural hazards research more broadly has widely recognized that women are more vulnerable to natural disasters, and female scientists in other natural hazard disciplines have brought an important perspective to the research that facilitates understanding and reducing such gender disparities. An equivalent gender dialogue does not yet exist in wildfire science but will be necessary to reduce vulnerabilities (e.g., smoke impacts on health, post-traumatic stress disorder following evacuation) and also understand the unique perspectives women have on 
wildfire as an ecological process. For example, women globally bear much of the childrearing duties; a key fire science question one might ask is whether acceptance of prescribed fire by communities is gendered based on perceptions of impacts to children?

The reader may also question the mixed genders of the authors of this editorial. Many proponents of increased recognition of women in science have highlighted that a major part of the problem has been that not enough male allies stand up publicly for their female colleagues, in part because some are embarrassed, fearful, or even feel, and are sometimes told by their colleagues, that it is not their place' [3-5]. Such acts of omission have in turn allowed cultures of disparity and inequality to continue, in large part, because men benefit from it. In essence, silence in the face of inequity constitutes approval. However, when male allies do publicly stand up alongside their female colleagues to join the chorus of saying, "no more", they can help their female colleagues' inspired efforts gain more iron and traction [6-8]. Further, a common problem observed in academia is that requiring women to take on the task of closing gender inequality gaps by themselves through increased service (e.g., committee representation) yields a substantial 'productivity tax [9];' male allies sharing the burden helps to alleviate this tax.

As wildfire risk is a product of complex socioecological relationships with fire [10] and wildfire losses are projected to increase with global climate change [11], it is critical to have a diversity of representation in fire research and to recognize the value that this diversity can bring to the discipline. Women fire scientists have contributed significant new insights and perspectives that bode well for the future of fire science. For example, female scientists have led recent high-impact articles that have demonstrated the need to integrate human factors to adequately address fire science challenges [12-14].

One facet of gender and education literature explores factors that are critical to expanding the role and influence of female scholars in STEM fields. Numerous studies identify the importance of role models to meeting this objective [15-17]. To this end, we sought to highlight key women working in fire science today. There is a distinct need to increase recognition of the number of women in fire sciences; a quick accounting of five recent fire science conferences found that women gave only $30 \%$ of oral presentations, with an even smaller proportion presenting plenary scientific talks. We introduce women who have made significant contributions over the course of a long career, and we present others who are relatively early in their career but are defining emerging key questions in fire research today. These women come from across the globe, and they are conducting research in a wide array of subdisciplines within fire science. They include distinguished members of national scientific academies, university academics, and both government and non-governmental organization employees. They all, however, have made fire a substantial research emphasis and will likely make critical contributions to fire science for years to come, both through their discoveries and as role models.

\section{Approach}

Any time one seeks to acknowledge a representative group, the first challenge is developing a set of criteria for inclusion, and unintended exclusions will inevitably result. In the absence of a heuristic for identifying women leaders in fire science, we developed this list through our own knowledge of the discipline and conversations across an extended network of international collaborators and then attempted to apply some more objective criteria. The scientists listed here are broadly in chronological order from the year of their first publication to highlight both established and up-and-coming leaders. Approximate year of first publication (excluding thesis or dissertation) and research emphasis areas were collated from public vitae, institutional and personal websites, ResearchGate, Google Scholar, and Web of Science, as available. Those that were included each had an H-index above 15 as of the date of this editorial, as determined through either Google Scholar or Web of Science. In cases where both Google Scholar and Web of Science information was available, the higher H-index was used. We acknowledge that the use of any break point is completely arbitrary; however, this enabled an objective assessment of scientists to include in this initial list. 
We also acknowledge that there are limitations to using the $\mathrm{H}$-index as the metric to initially select scientists for this list. The H-index was originally designed as a predictive tool of future scientific productivity [18] and, by design, is a function of age, as with time more opportunities exist for articles to be cited [19]. This, however, can lead to a decrease in H-index values for female early-career scientists, as they are more likely to take breaks in activity or begin academic careers at a later life-stage, as compared with their male counterparts [20]. In the physical science and natural sciences, recent studies have also demonstrated that women scientists receive significantly fewer citations compared with their male counterparts, which in turn will lead to lower H-index values [21-23]. However, given that this editorial focuses solely on women scientists, these effects should be normalized. The H-index threshold of 15 was selected, as it exceeded, by 1, the mean value presented by the designer of the $\mathrm{H}$-index as that typically observed when scientists attain a rank comparable to that of an associate professor [18].

We freely acknowledge that this is an initial list and that there are many additional women making important contributions to fire science that we have not included here. The leaders highlighted in this editorial, as well as additional diversity leaders will be encouraged to submit an article to the Special Collection, entitled "Diversity Leaders in Fire Science". Although the submissions could follow any article type published in Fire, we would encourage Perspectives and Concept Papers. In addition to invited contributions, the journal would also greatly welcome perspectives highlighting diversity issues and initiatives in fire science. Our hope is that over time, this Special Collection can help break down some of the barriers inhibiting more diverse representation in fire science.

\section{Recognizing Women Leaders in Fire Science}

Haiganoush K. Preisler is a statistical scientist at the United States Forest Service. Dr. Preisler's research focuses on the development of probability risk models and approaches to improving the predictions that disturbances such as fires and insect outbreaks have on forest ecosystems. Her notable works include the development of a probability-based model for assessing the risk of wildfires [24] and the modeling of California wildfire occurrences and areas burned under climate change [25]. Her recent works have included a near-term prediction of significant wildfire events for the western United States [26] and the development and incorporation of wildfire simulations in the virtual landscapes Envision modeling system [27]. In additional to articles in international journals, Dr. Preisler has published five general technical reports.

Lynda D. Prior is a research fellow at the University of Tasmania. Dr. Prior is an associate editor of the journal, Fire. Dr. Prior's research focuses on fire ecology, with a focus on the impacts of fires on tree demography, fine fuel flammability, and the eco-physiological impacts of fire on the conifer Callitris. Her notable works include the growth of trees under warming climates and fire [28,29] and research advancing our understanding of plant flammability [30]. Her recent work has included developing new frameworks for conceptualizing flammability [31].

Susan G. Conard is an emeritus ecologist at the United States Forest Service and is the current co-editor-in-chief of the International Journal of Wildland Fire. Dr. Conard is widely known for her work on carbon emissions of fires. Her notable works include one of the earliest spatial assessments of fire severity and the impacts of fire on carbon cycling in Russian boreal forests [32,33] and the development of new algorithms for determining carbon cycle products in satellite sensor imagery [34]. Her recent work has included evaluating the pine forest succession following high-intensity fires [35] and an editorial article highlighting the 25th anniversary of the International Journal of Wildland Fire [36].

Cathy L. Whitlock is a professor of earth sciences at Montana State University. Dr. Whitlock's research focuses on quaternary climate change and the role of humans and climate change in forming fire regimes. Her notable works include assessing the climate controls of fire occurrence and large-scale patterns in the Holocene [37] and reconstructing multi-thousand-year-old fire histories [38,39]. Her recent works have included contributions to a synthesis calling for more adaptation to wildfires 
in western North American forests [14] and further research on late-glacial and Holocene fire activity $[40,41]$.

Ruth DeFries is a professor of ecology and sustainable development at Columbia University in New York. Dr. DeFries is also a member of the National Academy of Sciences. Dr. DeFries's research focuses on understanding how the global demand for ecosystem goods and services are impacting land use, biodiversity, and human development. Her notable works include an assessing of deforestation due to urban population growth and agriculture [42,43], contributions to the global synthesis of global fire challenges [44,45], and the impacts of deforestation, fire, and drought in the Amazon basin [46]. Her recent works have included assessing the impacts of biomass burning on air pollution $[47,48]$ and a recent review that presented that ecosystem management should be considered as a wicked problem [49].

Constance I. Millar is a senior research ecologist with the Pacific Southwest Research Station of the United States Forest Service. Dr. Millar's research focuses on historic and ongoing climate change in high-elevation forest ecosystems of the Great Basin Mountains, including the eastern Sierra Nevada. Her notable works include a seminal thought paper that presented a conceptual framework for how to manage forest ecosystems in the future when the exact future is uncertain [50] and a synthesis of forest health when considering fires and insect disturbances interacting with droughts and other disturbances [51]. Her recent work has included the identification of climate refugia in low-elevation ravines [52].

Jennifer Harden is a scientist emeritus at the United States Geological Survey. Dr. Harden's research focuses on geology, paleoclimates, carbon cycling, and biogeochemical cycling in soil systems. In recent years, Dr. Harden has shifted her focus to also include the impacts of disturbances such as wildfires, erosion, and permafrost degradation on soil carbon and nutrient cycling. Dr. Harden is a fellow of the American Association for the Advancement of Science. Her notable works include the impacts of boreal forests on climate change [53] and understanding the role that fires play in the boreal carbon budget $[54,55]$. Her recent work has included a focus on improving understanding of soil carbon and nitrogen sequestration rates [56].

Monica G. Turner is the Eugene P. Odum Professor of Ecology and the Vilas Research Professor at the University of Wisconsin-Madison. Dr. Turner is also a member of the National Academy of Sciences. Dr. Turner's research focuses on understanding the drivers and impacts of landscape heterogeneity. Her notable works include the importance of scaling when considering landscape patterns [57,58], assessments of biogeochemical cycling following wildfires [59], and assessing the impacts of fires on landscape dynamics such as within Yellowstone National Park [60-62]. Her recent works have included a focus on ecosystem services $[63,64]$ and contributions to a synthesis calling for more adaptation to wildfires in western North American forests [14].

Carolyn H. Sieg is a research ecologist at the Rocky Mountain Research Station, United States Forest Service in Arizona. Dr. Sieg's research focuses on improving the understanding of how to effectively manage forests that are impacted by severe wildfires insect infestations and invasive plant species. Her notable works include evaluating the fire history within the interior ponderosa pine forests found in South Dakota $[65,66]$. Her recent works include understanding the role of high-severity fires on spatial patterns of ponderosa pine regeneration [67] and the interactions of fires and bark beetles in ponderosa pine forests [68].

Carla M. D'Antonio is a professor of ecology at the University of California, Santa Barbara. Dr. D'Antonio's research focuses on problems at the interface of plant community ecology and ecosystem ecology. Her notable works include furthering the understanding of the pathways and processes that drive the impacts of exotic plant invasions on ecosystem structure and function [69] and the impacts of invasive species on disturbance regimes [70-72]. Her recent work includes a 25-year assessment of how fire followed by invasive grasses has prevented a subtropical woodland from returning to the pre-fire ecosystem condition [73]. 
Penelope Morgan is a professor at the University of Idaho and is certified as a senior fire ecologist by the Association for Fire Ecology. Dr. Morgan's research focuses on understanding patterns and drivers of post-fire heterogeneity. Her notable works include studies to further understand the role of promoting natural variability in management strategies to promote biological diversity [74] and assessing fire regimes and fire effects at landscape scales $[75,76]$. Her recent works have included focusing on improving the extension of fire science synthesis to land managers [77], evaluating over one hundred years of high severity data to evaluate potential trends [78], and contributions to a synthesis calling for more adaptation to wildfires in western North American forests [14].

Dominique Bachelet is a senior climate change scientist and associate professor at Oregon State University. Dr. Bachelet's research focuses on the impacts of vegetation due to climate change and disturbances. Her notable works include assessing the impacts of climate change on both the distribution of vegetation and associated impacts on carbon budgets [79-82]. Her recent work has included contributing to a large synthesis on the current status of global fire modeling [83].

Mary A. Arthur is a professor of forest ecology at the University of Kentucky. Dr. Arthur's research focuses on the biogeochemistry of Rocky Mountain subalpine forests, the fire ecology of upland oak ecosystems, and ecosystem processes related to non-native invasive species. Her notable works include the impacts of repeated fires on the survival and regeneration of plant species in oak-pine forests [84] and nitrogen cycling in forested ecosystems $[85,86]$. Her recent works include assessments of how fuel composition, stand structure, and forest health changes in Appalachian hardwood forests after repeated fires $[87,88]$.

Anna Sala is a professor at the University of Montana. Dr. Sala's research focuses on plant physiology and mechanisms, with an emphasis on trees, in response to ecosystem disturbances such as fire, beetles, and drought. Her notable works include furthering the understanding of the mechanisms behind drought-induced mortality of trees $[89,90]$, furthering the understanding of carbon and non-structural-carbohydrate dynamics within trees [91,92], and understanding how fire alters nitrogen dynamics in ponderosa pine stands [93]. Her recent works have included furthering the understanding of genetic effects in tree survival [94] and assessing the ability of fires and thinning to help increase resistance to beetle attacks $[95,96]$.

Maria J. Perestrelo de Vasconcelos is a researcher with the Instituto de Investigação Científica Tropical in Portugal. Dr. Vasconcelos's research focuses on forest monitoring, land-use and landcover change, and climate change. Her notable works include an evaluation of logistic regression and neural network methods to spatially predict fire ignitions [97] and an assessment of what landcover types in Portugal are more likely to exhibit wildfires [98]. Her recent work includes the development of a new method to assess burned areas in satellite sensor imagery [99].

Beverly E. Law is a professor of global change biology and terrestrial systems science at Oregon State University. Dr. Law is a fellow of the American Geophysical Union and an Aldo Leopold Leadership Fellow. Dr. Law's research focuses on the impacts of fires, climate change, and land management on carbon and water cycling. Her notable works include assessments of carbon cycling in temperate and boreal forests that include fires [100-102]. Her recent works include assessing tree mortality from fires, harvesting, and bark beetles during an extended period of drought in the western United States [103] and an assessment of land-use strategies to mitigate carbon dioxide emissions [104].

Vanya R. Pivello is a professor of ecology at the University of Sao Paulo. Dr. Pivello's research focuses on the ecology of the Cerrado of Brazil. Her notable works include understanding the role of invasive grasses on the biodiversity of the Cerrado [105] and a synthesis of human use of fire in both the Cerrado and the Amazon rainforest [106]. Her recent work has included understanding the role of fire on seed germination in neotropical savannas [107].

Nancy H.F. French is the deputy and senior scientist of the Environmental, Transportation, and Decision Support Lab at the Michigan Tech Research Institute. Dr. French's research focuses on the spatial characterization of fires and fire emissions. Her notable works include assessments of changes in boreal forests under climate change [108], evaluating burned areas in Alaskan boreal forests [34,109], 
and evaluating burn severity in North American boreal forests [110]. Her recent works have included improvements to regional atmospheric $\mathrm{CO}_{2}$ inversion models [111] and impacts of fires on land surface albedo in the Alaskan tundra [112].

Janice L. Coen is a project scientist at the National Center for Atmospheric Research in Boulder, Colorado. Dr. Coen's research focuses on wildland fire behavior and its interaction with weather. Her notable works include research to develop coupled atmosphere-fire models $[113,114]$. Her recent work includes a simulation of a windstorm-driven wildfire in Colorado [115].

Mercedes Bustamante is an associate professor of ecology at the Universidade de Brasilia. Dr. Bustamante in 2014 was the first corresponding author to the Intergovernmental Panel on Climate Change (IPCC) Working Group III, Mitigation of Climate Change, Agriculture, Forestry, and Other Land Uses [116]. Dr. Bustamante's research focuses on plant physiology and fire in savanna ecosystems. Her notable works include contributions to syntheses relating to nitrogen deposition impacts on plant diversity [117] and the impacts of deforestation, fire, and drought in the Amazon basin [46]. Her recent work has included the development of an integrated monitoring approach for assessing the impacts of tropical forest degradation and impacts on carbon and biodiversity [118].

Tina L. Bell is an associate professor at the University of Sydney. Dr. Bell's research focuses on fire ecology, soil-plant interactions, and smoke. Her notable works include a response to fire of root morphology, anatomy, and starch distributions in the southwest of the Australian Epacridaceae [119] and the post-fire growth to the southwestern Australian Epacridaceae [120]. Her recent works have included understanding the impacts of fuel reduction to optimize post-fire carbon-, water-, and vegetation-related ecosystem goods and services [121,122].

Michelle C. Mack is a professor of ecosystem ecology at Northern Arizona University. Dr. Mack's research focuses on plant community ecology and what biological and environmental drivers impact ecosystem dynamics under global change. Her notable works include contributions to a synthesis seeking to further understand the impacts of changing biodiversity on ecosystem processes and resilience [123], the impacts of nutrient fertilization on carbon storage in the Arctic Tundra [124], and the impacts of invasive species on disturbance regimes [67], and assessing how fires in boreal and arctic systems impact carbon processes and radiative forcing [53,125]. Her recent work includes an analysis of tree rings in black spruce forests to predict future ecosystem resilience to fires [126].

Ana Isabel Couto Neto da Silva Miranda is a professor at the Universidade de Aveiro in Portugal. Dr. Miranda's research focuses on emissions, air quality modeling, and climate change. Her notable works include furthering the understanding of the sources of particulate matter in Europe [127] and modeling fire activity, air quality, and particulate matter emissions in Portugal [128-131]. Her recent works have continued to build on furthering the understanding of particulate matter emissions [132,133].

Karla M. Longo de Feritas is a senior scientist at the National Aeronautics and Space Administration. Dr. Longo's research focuses on the remote sensing of biomass burning in South America. Her notable works include contributions to characterize fire emissions during the Smoke, Clouds, and Radiation-Brazil (SCAR-B) experiment [134,135] and research to assess plume rise in vegetation fires [136]. Her recent works include evaluating emissions form Cerrado fires and modeling the impacts of biomass burning aerosol emissions from Amazonian fires [137,138].

Amy Hessl is a professor of geography at West Virginia University. Dr. Hessl's research focuses on the interactions between humans, past climates, and forest ecosystem processes. Her notable works include an evaluation of the impacts of drought and regional climate on fire occurrence in the northwestern United States [139,140] and the interaction of fires, herbivory, and humans on aspens stands in western Wyoming [141]. Her recent works have included an assessment of climate and fire in Mongolia over the last 500 years [142] and contributions to an article calling for advances in the use of dendrochronological assessments of fires in the United States [143].

Jill F. Johnstone is a freelance researcher at the Northern Plant Ecology Lab (NPEL). Dr. Johnstone was formerly a professor at the University of Saskatchewan and is now an adjunct professor at the 
University of Saskatchewan and an affiliate research scientist at the University of Alaska, Fairbanks. Dr. Johnstone's research focuses on how disturbances and climate interact to impact boreal and tundra ecosystem dynamics. Her notable works include how changes in fire regimes are altering Alaskan boreal forests [144-146] and how fire impacts on soils impact post-fire tree recruitment and regeneration in boreal forests [147]. Her recent works include an analysis of tree rings in black spruce forests to predict future ecosystem resilience to fires [126] and a synthesis looking at ecological memory and forest resilience under changing disturbance regimes [148].

Rebecca B. Bird is a professor of anthropology at Penn State University. Dr. Bird's research focuses on human behavioral ecology, fire ecology, indigenous conservation and land management, signaling theory, and landscape ecology. Her notable works include seminal work in signaling theory [149] and assessments of Australian Aboriginals' use of fire [150-152]. Her recent works have included the role of Aboriginal burning on promoting fire diversity and native predators [153] and work exploring human-climate-fire relationships [154].

Toddi A. Steelman is the Stanback Dean of the Nicholas School of the Environment at Duke University. Dr. Steelman's research focuses on governance, community decision making, and policy associated with environmental and natural resource governance, as well as adaptation, mitigation, preparedness, and response to wildfires. Her notable works include understanding perspectives of land management personnel and the public in natural resource decision making $[155,156]$. Her recent works have included evaluating what types of information people trust and find useful during wildfire disasters [157] and contributions to a synthesis evaluating wildfire risk in socioecological systems [12].

Meg A. Krawchuk is an assistant professor at Oregon State University. Dr. Krawchuk's research focuses on landscape ecology, biogeography, and conservation science. Her notable works include projections of future global geographic distributions of wildfires [158] and furthering the understanding of the biotic and abiotic constraints on fire occurrence $[159,160]$. Her recent works have included further understanding the spatial patterns of burned areas, refugia, and fire occurrence [161-163] and contributions to a synthesis calling for more adaptation to wildfires in western North American forests [14].

Fay H. Johnston is an associate professor at the University of Tasmania and a senior research fellow at the Menzies Institute for Medical Research. Dr. Johnston's research focuses on assessing environmental factors on poor health such as the epidemiology of smoke pollution, as well as health impacts of airborne allergens and heatwaves. Her notable works include human impacts of wildfires, such as public health costs and projected mortality rates from smoke exposure [38,164-166]. Her recent works continue to build on research to quantify the health and economic impacts on the public from wildfire smoke [167], as well as other studies aimed at better informing the public of the air quality risk [168].

Yufang Jin is an associate professor at the University of California, Davis. Dr. Jin's research focuses on ecosystem responses to climate change, fires, and management. Her notable works include contributions to a synthesis of global fire emissions [169], the impacts of boreal forests on climate change [53], and the assessment of burn severity and vegetation recovery in North American boreal forests [170]. Her recent works include evaluating the potential for different fire regimes within Southern California [171] and an assessment of fires in Southern California under periods with and without Santa Ana winds [172].

Kendra K. McLauchlan is a professor at Kansas State University. Dr. McLauchlan's research focuses on characterizing the properties of past ecosystems through reconstructing biogeochemical cycling, fire histories, and vegetation in grassy ecosystems. Her notable works include evaluating nitrogen cycle dynamics during the Holocene [173] and work to reconstruct disturbance histories and their impacts on biogeochemical cycling [174]. Her recent work has included reconstructing fire history in grasslands using sedimentary charcoal [175].

Lori D. Daniels is a professor at the University of British Columbia. Dr. Daniels' research focuses on the use of dendroecological methods to assess the impacts of climate and disturbances 
on the vegetation dynamics of temperature forests. Her notable works include the role of climate on the altitudinal tree lines [176] and contributions to a synthesis furthering the understanding of tree mortality rates across the western United States [177]. Her recent works have included assessing the roles of humans and climate on fire regimes [178] and improving approaches to derive mean fire intervals [179].

Christelle Hély is faculty at the École Pratique des Hautes Études, a college of the Paris Sciences \& Lettres (PSL) Research University in Paris. Dr. Hély's research focuses on forest ecosystem responses to climate change, modeling, and fire science. Her notable works include the impacts of vegetation and weather on predicted fire behavior in boreal forests $[180,181]$ and understanding dynamics of vegetation and fires in Africa and boreal North America during the Holocene [182,183]. Her recent work has included understanding the drivers behind extreme fires in Mediterranean regions of France [184].

Catherine L. Parr is a professor of ecology at the University of Liverpool. Dr. Parr's research focuses on invertebrates and how they interact within the context of savanna ecology, community ecology, and fire ecology. Her notable works include understanding the impacts of spatial burn heterogeneity on biodiversity in tropical and subtropical savannas [185], the effects of savanna fires on ant communities [186], and further understanding tropical grassy biomes [187]. Her recent work has included a synthesis that called for further research into the evolutions and adaptations that have occurred in animals in response to fire [188].

Carol Miller is a research ecologist at the Aldo Leopold Wilderness Research Institute. Dr. Miller's research focuses on assessing the biophysical drivers behind fire regimes, investigating interactions between fire regimes, climate, and the patterns and processes of vegetation, assessing the balance between fire suppression and restoring fire within functioning ecosystems, and evaluating the impacts of climate on fire regimes. Her notable research includes furthering the understanding of scaling when considering fire regimes [189] and synthesizing risk analysis approaches used in wildland fire management [190]. Her recent works have included assessing refugia following large fires [161,191] and a synthesis of progress in wilderness fire science [192].

Tania Schoennagel is a research scientist at the University of Colorado. Dr. Schoennagel's research focuses on the causes and impacts of fires and other disturbances on western forests. Her notable works include a study evaluating the interaction of fires, fuels, and climate [193], research on the role of droughts on fire occurrence in subalpine forests [194], an assessment of national fire plan treatments in the wildland urban interface [195], and contributions to a synthesis focusing on how to adapt and coexist with wildfires [196]. Her recent work includes a synthesis calling for improved human adaptation to wildfires in western North American forests [14].

Dolors Armenteras is a professor of landscape ecology at the Universidad Nacional de Colombia. Dr. Armenteras's research focuses on fire ecology, biodiversity, deforestation, and land-use work in conservation and sustainability. Her notable works include an assessment of the patterns and drivers of deforestation in the Colombian Amazon [197] and a study of the influence of forest fragmentation on fire occurrence and intensity in forests in Amazonia [198]. Her recent works include evaluating changing patterns of fire occurrence in tropical Amazon forests [199] and predicting reducing emissions from deforestation and forest degradation (REDD) deforestation rates from remote sensing fire products [200].

Ana Alencar is the program director at the Amazon Environmental Research Institute (IPAM) in Brazil. Dr. Alencar's research focuses on fires in Brazil, with a focus on environmental policy and sustainability. Her notable works include contributions to syntheses evaluating the impacts of fires, deforestation, and land-use in forests in Amazonia [201,202]. Her recent works have included contributions to articles seeking a policy solution to Brazil's illegal deforestation [203] and the development of an integrated monitoring approach for assessing the impacts of tropical forest degradation and impacts on carbon and biodiversity [118]. 
Christine Wiedinmyer is the associate director for science at the Cooperative Institute for Research in Environmental Sciences (CIRES), which is a partnership between the National Oceanic and Atmospheric Administration and the University of Colorado. Dr. Wiedinmyer's research focuses on how land-use and landcover change impact the emissions of trace gases and particulates and how they in turn impact atmospheric composition, air quality, and climate. Her notable works include a synthesis of global terrestrial isoprene emissions using the model of emissions of gases and aerosols from nature (MEGAN) [204], the development of high-resolution models to estimate emissions from biomass burning [205], and integrating fire emissions into air quality assessments [206]. Her recent work has included improving information on black carbon deposition on the Greenland ice sheet [207].

Alexandra D. Syphard is a senior research scientist at the Conservation Biology Institute in Oregon. Dr. Syphard's research is focused on how landscapes change under human and natural disasters, with an emphasis on wildfires, urbanization, and climate change. Her notable works include characterizing the human impacts on California fire regimes [208], the evaluation of spatial patterns from wildfires [209], and contributions to a synthesis on how to coexist with wildfires [196]. Her recent work has included evaluating the increased risk of wildland fires due to rapid urbanization [210].

Valerie Trouet is an associate professor at the University of Arizona. Dr. Trouet's research focuses on using tree-rings to study past climates and forests, with a focus on fire-climate interactions, carbon cycle science, and human-environment interactions. Her notable works include climate reconstructions and fire-climate interactions over the last 100-500 years [211-213]. Her recent works include understanding the role of sociological factors in impacting fire activity over the last 400 years in the Sierra Nevada [214] and evaluating the impacts of fires on season radial growth in trees [215].

Erica D. Kuligowski is the lead scientist and sociologist in the Wildland Urban Interface (WUI) Fire Group of the Fire Research Division of the Engineering Laboratory at the National Institute of Standards and Technology (NIST). Dr. Kuligowski's research focuses on developing science to lower the risk of fire spread in WUI communities and the development of improved public alert systems for fire risk. Her notable works include furthering the understanding of how humans react during fires [216]. Her recent work has included research on evacuations from structures [217].

Emily K. Heyerdahl is a research forester with the United States Forest Service. Dr. Heyerdahl's research focuses on the spatial and temporal variation of historical fire regimes. Her notable works include understanding the spatial variation and climate drivers of fire regimes [218,219]. Her recent works have included mortality assessments of ponderosa pine 21 years after fire-scarred partial cross-sections were removed [220] and the role of low-severity fires in increasing tree defenses to bark beetles [95].

Erica A. H. Smithwick is an associate professor of geography at the Pennsylvania State University. Dr. Smithwick's research focused on the interactions of landscape and ecosystem ecology with an emphasis on pyrogeographic impacts on biogeochemistry and carbon dynamics. Her notable works include assessments of biogeochemical cycling following wildfires $[59,221]$ and understanding carbon storage in Pacific Northwest forests [222]. Her recent works have included a correspondence calling for the fire science community to include social and economic factors within wildfire risk assessments [223].

Sally Archibald is an associate professor at the University of the Witwatersrand. Dr. Archibald's research focuses on the dynamics of savanna ecosystems under fire, grazing, and global change. Her notable works include further understanding the fire-tree-grazer cycles in global savannas [224-227] and assessing what factors limit burned areas in southern Africa [228]. Her recent works have included further understanding the role of humans in these dynamic savanna ecosystems [229] and contributions to a synthesis to consider the plant characteristics that lead to the flammability of ecosystems [230].

Jennifer Marlon is a research scientist at the Yale School of Forestry and Environmental Science. Dr. Marlon's research focuses on the social and physical factors of climate change to assess human perceptions to extreme events and reconstruct past climates, respectively. Her notable works include evaluating the climatic and human drivers in global biomass burning events over the last 2000 years [231,232] and the response of North American wildfires to abrupt changes in climate [233]. 
Her recent works have included reconstructing biomass burning records of fire location, timing, spatial extent, and frequency [234].

Alessandra Fidelis is an assistant professor at the Universidade Estadual Paulista in Brazil. Dr. Fidelis's research focuses on understanding how fire affects tropical savannas and grassland, with an emphasis on using fire to manage invasive species and vegetation dynamics. Her notable works include contributions to a synthesis on current ecological knowledge of the South Brazilian Campos biome [235]. Her recent work includes assessments of fire behavior and effects on plants and seeds in Cerrado fires [236,237].

Claire M. Belcher is an associate professor in earth system science at the University of Exeter. Dr. Belcher's research focuses on the impact and flammability of wildfires in both contemporary and ancient ecosystems. Dr. Belcher's work seeks to further understand what role wildfires play in maintaining the various earth-system processes that enable the Earth to be habitable. Dr. Belcher recently edited "Fire Phenomena and the Earth System: An interdisciplinary Guide to Fire Science" [238]. Notable works by Dr. Belcher include understanding the lower limits of oxygen under wildfires that occurred in the Mesozoic [239] and the flammability of Earth's ecosystems during the Carboniferous through the present periods of Earth's history [240]. Her recent work has included contributions to a synthesis to consider the plant characteristics that lead to the flammability of ecosystems [230].

Sarah M. McCaffrey is a research forester with the United States Forest Service. Dr. McCaffrey's research focuses on improving the understanding of the social factors and dynamics of fire management. Her notable works include further understanding the role of social science research in wildfire management [241] and contributions to a synthesis focusing on how to adapt and coexist with wildfires [196]. Her recent works have included a synthesis of lessons learned in public responses to wildfires from 2010-2015 [242] and evaluating what types of information people trust and find useful during wildfire disasters [157].

Tatiana V. Loboda is an associate professor at the University of Maryland. Dr. Loboda's research focuses on the interactions of wildland fires, biodiversity, public health, and local change with human and physical landscape properties. Her notable works include the development of new algorithms for determining burned area and carbon cycle products in satellite sensor imagery [34] and assessing fire risk in Russia [243]. Her recent works have included efforts to assess black carbon emissions from cropland burning in Russia, with impacts on the Arctic [244,245].

Bethany Bradley is an associate professor at the University of Massachusetts at Amherst. Dr. Bradley's research focuses on plant invasion and fire ecology, biogeography, and modeling the risk and potential shifts of plant invasions under global change. Her notable works include modeling potential risks of species invasions [246,247] and documenting the role of introduced grass species on fire activity in the western United States [72]. Her recent works have included evaluating the role of cheatgrass distribution on fire regimes [248] and the role that human ignitions and high winds play in promoting the occurrence of large wildfires $[13,249,250]$.

Sofia Bajocco is a researcher at the Council for Agricultural Research and Economics - Research Centre for Agriculture and Environment (CREA-AA) in Italy. Dr. Bajocco is on the editorial board of the journal, Fire. Dr. Bajocco's research focuses on landscape ecology, vegetation phenology, fire ecology, and remote sensing. Her notable works include assessments of what landcover classes in Italy are most sensitive to desertification and wildfires [251,252]. Her recent works have included studies to assess the linkages between fire ignitions and fuel phenology [253] and the spatial mapping of forest fuels via phenology [254].

A. Paige Fischer is an assistant professor at the University of Michigan. Dr. Fischer's research focuses on human behaviors in response to natural hazards and climate change impacting the sustainability of socioecological systems. Her notable works include the integration of traditional ecological knowledge and local ecological knowledge when considering conservation of forest biodiversity [255] and furthering the understanding of fire-affected landscapes as coupled human and ecological systems [256]. Her recent work has included leading a synthesis where risk of wildfires is 
characterized by a complex array of challenging interactions between social and ecological systems across scales [12].

Sarah B. Henderson is an assistant professor at the University of British Columbia and the senior environmental health scientist at the British Columbia Center for Disease Control. Dr. Henderson's research focuses on air pollution, extreme weather events, and environmental health and safety. Her notable works include projected health impacts and mortality rates from smoke exposure [166,257]. Her recent works include improved methods to predict the minimum height of forest fire smoke [258] and improving approaches to better understand the health impacts of fires on the public [259].

Jennifer K. Balch is an assistant professor at the University of Colorado-Boulder. Dr. Balch is on the editorial board of the journal, Fire. Dr. Balch's research focuses on the patterns and processes of fire disturbances and the recovery of ecosystems. Dr. Balch's work seeks to understand the sustainability of tropical and other fire-affected ecosystems. Notable works by Dr. Balch include documenting the role of introduced grass species on fire activity in the western United States [72] and the role of fires in Amazonia and other tropical regions $[46,260]$. Her recent works have included being the corresponding author to a global synthesis of global fire challenges [44] and research focused on understanding the role of climate and a wider assessment of what triggers a fire season [249,261], studies of the role that human ignitions and high winds play in promoting the occurrence of large wildfires $[13,250]$, and contributions to a synthesis calling for improved human adaptation to wildfires in western North American forests [14].

Crystal A. Kolden is an associate professor at the University of Idaho. Dr. Kolden is on the editorial board of the journal, Fire. Dr. Kolden's research focuses on the relationships between climate and fire, the impacts of fires on socio-ecological-hydrological systems, and the remote sensing of fuels and fire effects. Her notable works include studies to assess the relationships between climate and burned areas [262] and assessing unburned areas and refugia within fire perimeters [263,264]. Her recent works have included a synthesis focused on how to live with fires across the world [10], assessing future worldwide increases in fire activity and risks to human populations [11], and an analysis of the spatial distribution of the 2017 Californian wildfires that were ignited under katabatic or non-katabatic wind conditions [265].

Caroline E. R. Lehmann is a senior lecturer at the University of Edinburgh. Dr. Lehmann focuses on the ecology and evolution of tropical ecosystems, with an emphasis on savannas and how their dynamics are impacted by climate and fire. Dr. Lehmann has also worked on improving our understanding of the evolution of $\mathrm{C} 4$ grasslands and improving knowledge of how savannas and tropical biomes are defined more broadly. Her notable works include describing the distributions of savannas [266] and further understanding the global dynamics of savanna vegetation-fire-climate relationships [28,226]. Her recent works have included assessing the degree of savanna woody encroachment [267] and further understanding tropical grassy biomes [187].

Sharon M. Hood is a research ecologist with the United States Forest Service. Dr. Hood's research focuses on the mechanisms of post-fire tree mortality, the impacts of changing fire regimes on forest succession and resilience, and the impacts of fire on the susceptibility of bark beetles to attack trees. Her notable works include research to evaluate post-fire conifer mortality $[90,94,268]$. Her recent works have continued to build on post-fire tree mortality [269], assessing the ability of fires and thinning to help increase resistance to beetle attacks $[95,96]$, as well as assessing the long-term impacts of fuel treatments [270].

\section{Special Mentions}

This section recognizes scientists that published predominately technical reports or national journal titles that do not register in Web of Science. Although the data for these scientists was incomplete, each has contributed significantly to fire science, and we wanted to err on the side of inclusion. 
Elizabeth Reinhardt was formerly the assistant director of fire and aviation management at the United States Forest Service. Dr. Reinhardt's research broadly focused on fuels and fire ecology. Her notable works include the development of models to develop post-fire mortality, fire effects, and burning rates of large woody fuels [271-273]. In additional to articles in international journals, Dr. Reinhardt has published 14 general technical reports.

Patricia Andrews was formerly a research physical scientist at the United States Forest Service Missoula Fire Sciences Laboratory. Dr. Andrew's research focused on science integration and the application of fire behavior and fire danger research. Her notable works include advances in the understanding of fire danger [274] and the development of the BehavePlus fire modeling system [275]. In additional to articles in international journals, Dr. Andrews has published six general technical reports.

Sue A. Ferguson (deceased) was formerly a member of the Fire and Environmental Research Applications Team at the Pacific Northwest Research Station of the United States Forest Service. Dr. Ferguson founded the Atmosphere and Fire Interactions Research and Engineering Team and the Northwest Regional Modeling Center. Her notable works included an assessment of lighting-based wildfire ignitions in the Pacific Northwest [276] and an article published posthumously recognizing that her work was instrumental in leading to the development of the BlueSky smoke prediction system [277].

\section{Conclusions}

We again acknowledge that this compilation in no way encompasses all current women leaders in fire science. Rather, it is merely an attempt to identify some of the prospective role models in fire science and intentionally initiate a scholarly conversation about the perspectives and epistemologies that diversity can bring to the field. Additionally, while our goal here was to highlight the rise of women in the field, we also acknowledge the need to recognize other underrepresented voices in the field, such as indigenous and racial minorities, individuals with disabilities, and the LGBTQIA community, who all bring different ways of doing and knowing to science.

Acknowledgments: The authors thank the editor and reviewers for their excellent and thoughtful comments.

Conflicts of Interest: The authors declare no conflicts of interest.

\section{References}

1. Rossi, A.S. Women in Science: Why So Few? Social and psychological influences restrict women's choice and pursuit of careers in science. Science 1965, 148, 1196-1202. [CrossRef] [PubMed]

2. Blickenstaff, C.J. Women and science careers: Leaky pipeline or gender filter? Gender Educ. 2005, 17, 369-386. [CrossRef]

3. Smith, D.G.; Johnson, W.B. Lots of men are gender-equality allies in private: Why not in public? Harvard Business Review, 13 October 2017.

4. Sherf, E.N.; Tangirala, S.; Weber, K.C. It is not my place! Psychological standing and men's voice and participation in gender-parity initiatives. Organ. Sci. 2017, 28. [CrossRef]

5. Ashcraft, C.; DuBow, W.; Eger, W.; Blithe, S.; Sevier, B. Male Advocates and Allies: Promoting Gender Diversity in Technology Workplaces; National Center for Women and information Technology: Boulder, CO, USA, 2013; p. 68.

6. Center for Women in Business. Men as Allies: Engaging Men to Advance Women in the Workplace; Bentley University: Waltham, MA, USA, 2017; p. 20.

7. Granger, S. Want to be an ally to women at work? Here are five things men in tech have been doing. Slate, 8 January 2018.

8. Sangster, E. 5 things men can do to be allies to women in the workplace. Forbes, 8 March 2018.

9. Zepeda, L. The harassment tax. Science 2018, 359, 126. [CrossRef] [PubMed] 
10. Smith, A.M.S.; Kolden, C.A.; Paveglio, T.; Cochrane, M.A.; Mortitz, M.A.; Bowman, D.M.J.S.; Hoffman, C.M.; Lutz, J.A.; Queen, L.P.; Hudak, A.T.; et al. The science of firescapes: Achieving fire resilient communities. BioScience 2016, 66, 130-146. [CrossRef] [PubMed]

11. Bowman, D.M.J.S.; Williamson, G.; Kolden, C.A.; Abatzoglou, J.T.; Cochrane, M.A.; Smith, A.M.S. Human exposure and sensitivity to globally extreme wildfire events. Nat. Ecol. Evol. 2017, 1, 0058. [CrossRef] [PubMed]

12. Fischer, A.P.; Spies, T.A.; Steelman, T.A.; Moseley, C.; Johnson, B.R.; Bailey, J.D.; Ager, A.A.; Bourgeron, P.; Charnley, S.; Collins, B.M.; et al. Wildfire risk as a socioecological pathology. Front. Ecol. Environ. 2016, 14, 277-285. [CrossRef]

13. Balch, J.K.; Bradley, B.A.; Abatzoglou, J.T.; Nagy, R.C.; Fusco, E.J.; Mahood, A.L. Human-started wildfires expand the fire niche across the United States. Proc. Natl. Acad. Sci. USA 2017, 114, 2946-2951. [CrossRef] [PubMed]

14. Schoennagel, T.; Balch, J.T.; Brenkert-Smith, H.; Dennison, P.R.; Harvey, B.J.; Krawchuk, M.A.; Mietklewicz, N.; Morgan, P.; Moritz, M.A.; Rasker, R.; et al. Adapt to more wildfire in western North American forests as climate changes. Proc. Natl. Acad. Sci. USA 2017, 114, 4582-4590. [CrossRef] [PubMed]

15. Smith, W.S.; Erb, T.O. Effect of women science career role models on early adolescents' attitudes toward scientists and women in science. J. Res. Sci. Teach. 1986, 23, 667-676. [CrossRef]

16. Etzkowitz, H.; Kemelgor, C.; Neuschatz, M.; Uzzi, B.; Alonzo, J. The paradox of critical mass for women in science. Science 1994, 266, 51-54. [CrossRef] [PubMed]

17. Buck, G.A.; Clark, V.L.P.; Leslie-Pelecky, D.; Lu, Y.; Cerda-Lizarraga, P. Examining the cognitive processes used by adolescent girls and women scientists in identifying science role models: A. feminist approach. Sci. Educ. 2008, 92, 688-707. [CrossRef]

18. Hirsch, J.E. Does the H index have predictive power? Proc. Natl. Acad. Sci. USA 2007, 104, $19193-19198$. [CrossRef] [PubMed]

19. Kreiner, G. The slavery of the h-index-Measuring the unmeasurable. Front. Hum. Neurosci. 2016, 10, 556. [CrossRef] [PubMed]

20. Holliday, E.B.; Jagsi, R.; Wilson, L.D.; Choi, M.; Thomas, C.R.; Fuller, C.D. Gender differences in publication productivity, academic position, career duration and funding among U.S. academic radiation oncology faculty. Acad Med. 2014, 89, 767-773. [CrossRef] [PubMed]

21. Caplar, N.; Tacchella, S.; Birrer, S. Quantitative evaluation of gender bias in astronomical publications from citation counts. Nat. Astron. 2017, 1, 0141. [CrossRef]

22. Bendels, M.H.K.; Muller, R.; Brueggmann, D.; Groneberg, D.A. Gender disparities in high-quality research revealed by Nature Index journals. PLoS ONE 2018, 13, e0189136. [CrossRef] [PubMed]

23. King, M.M.; Bergstrom, C.T.; Correll, S.J.; Jacquet, J.; West, J.D. Men set their own cites high: Gender and self-citation across fields and over time. Socius 2017, 3, 1-22.

24. Preisler, H.K.; Brillinger, D.R.; Burgan, R.E.; Benoit, J.W. Probability based models for estimation of wildfire risk. Int. J. Wildland Fire 2004, 13, 133-142. [CrossRef]

25. Westerling, A.L.; Bryant, B.P.; Preisler, H.K.; Holmes, T.P.; Hidalgo, H.G.; Das, T.; Shrestha, S.R. Climate change and growth scenarios for California wildfire. Clim. Chang. 2011, 109, 445-463. [CrossRef]

26. Preisler, H.K.; Riley, K.L.; Stonesifer, C.S.; Calkin, D.E.; Jolly, W.M. Near-term probabilistic forecast of significant wildfire events for the Western United States. Int. J. Wildland Fire 2016, 25, 1169-1180. [CrossRef]

27. Ager, A.A.; Barros, A.M.G.; Day, M.A.; Preisler, H.K.; Spies, T.A.; Bolte, D. Analyzing fine-scale spatiotemporal drivers of wildfire in a forest landscape model. Ecol. Model. 2018, 384, 87-102. [CrossRef]

28. Lehmann, C.E.R.; Prior, L.D.; Bowman, D.M.J.S. Fire controls population structure in four dominant tree species in a tropical savanna. Oecologia 2009, 161, 505-515. [CrossRef] [PubMed]

29. Prior, L.D.; Bowman, D.M.J.S. Big eucalypts grow more slowly in a warm climate: Evidence of an interaction between tree size and temperature. Glob. Chang. Biol. 2014, 20, 2793-2799. [CrossRef] [PubMed]

30. Bowman, D.M.J.S.; French, B.J.; Prior, L.D. Have plants evolved to self-immolate? Front. Plant Sci. 2014, 5, 590. [CrossRef] [PubMed]

31. Prior, L.D.; Murphy, B.P.; Bowman, D.M.J.S. Conceptualizing Ecological Flammability: An Experimental Test of Three Frameworks Using Various Types and Loads of Surface Fuels. Fire 2018, 1, 14. [CrossRef]

32. Conard, S.G.; Ivanova, G.A. Wildfire in Russia boreal forests-Potential impacts of fire regime characteristics on emissions and global carbon balance estimates. Environ. Pollut. 1997, 98, 305-313. [CrossRef] 
33. Conard, S.G.; Sukhinin, A.; Stocks, B.J.; Cahook, D.R.; Davidenko, E.P.; Ivanova, G.A. Determining effects of area burned and fire severity on carbon cycling and emissions in Siberia. Clim. Chang. 2002, 55, 197-211. [CrossRef]

34. Sukhinin, A.L.; French, N.H.F.; Kasischke, E.S.; Hewson, J.H.; Soja, A.J.; Csiszar, I.A.; Hyer, E.J.; Loboda, T.V.; Conard, S.G.; Romasko, V.I.; et al. AVHRR-based mapping of fires in Russia: New products for fire management and carbon cycle studies. Remote Sens. Environ. 2004, 93, 546-564. [CrossRef]

35. Ivanova, G.A.; Ivanov, V.A.; Kovaleva, N.M.; Conard, S.G.; Zhila, S.V.; Tarasov, P.A. Succession of vegetation after a high-intensity fire in a pine forest with lichens. Contemp. Problems Ecol. 2017, 10, 52-61. [CrossRef]

36. Conard, S.G.; Doer, S.; Foster, J. Twenty-five years of International Journal Wildland Fire. Int. J. Wildland Fire 2016, 25, 1. [CrossRef]

37. Whitlock, C.; Moreno, P.I.; Bartlein, P. Climatic controls of Holocene fire patterns in southern South America. Quat. Res. 2007, 68, 28-36. [CrossRef]

38. Long, C.J.; Whitlock, C.; Bartlein, P.J.; Millspaugh, S.H. A 9000-year fire history from the Oregon Coast Range, based on a high-resolution charcoal study. Can. J. For. Res. 1998, 28, 774-787. [CrossRef]

39. Millspaugh, S.H.; Whitlock, C.; Bartlein, P.J. Variations in fire frequency and climate over the past 17,000 yr in central Yellowstone National Park. Geology 2000, 28, 211-214. [CrossRef]

40. Stahle, L.N.; Chin, H.; Haberle, S.; Whitlock, C. Late-glacial and Holocene records of fire and vegetation from Cradle Mountain National Park, Tasmania, Australia. Quat. Sci. Rev. 2017, 177, 57-77. [CrossRef]

41. Fletcher, M.S.; Bowman, D.M.J.S.; Whitlock, C.; Mariani, M.; Stahle, L. The changing role of fire in conifer-dominated temperate rainforest through the last 14,000 years. Quat. Sci. Rev. 2018, 182, 37-47. [CrossRef]

42. Morton, D.C.; DeFries, R.S.; Shimabukuro, Y.E.; Anderson, L.O.; Aral, E.; Espirito-Santo, F.E.B.; Freitas, R.; Morisette, J. Cropland expansion changes deforestation dynamics in the southern Brazilian Amazon. Proc. Natl. Acad. Sci. USA 2006, 103, 14637-14641. [CrossRef] [PubMed]

43. DeFries, R.S.; Rudel, T.; Urlarte, M.; Hansen, M. Deforestation driven by urban population growth and agricultural trade in the twenty-first century. Nat. Geosci. 2010, 3, 178-181. [CrossRef]

44. Bowman, D.M.J.S.; Balch, J.K.; Artaxo, P.; Bond, W.J.; Carlson, J.M.; Cochrane, M.A.; D’Antonio, C.M.; DeFres, R.S.; Doyle, J.C.; Harrison, S.P.; et al. Fire in the Earth System. Science 2009, 324, 481-484. [CrossRef] [PubMed]

45. Bowman, D.M.J.S.; Balck, J.; Artaxo, P.; Bond, W.J.; Cochrane, M.A.; D'Antonio, C.M.; DeFries, R.; Johnston, F.H.; Keeley, J.E.; Krawchuk, M.A.; et al. The human dimension of fire regimes on Earth. J. Biogeogr. 2011, 38, 2223-2236. [CrossRef] [PubMed]

46. Davidson, E.A.; de Araujo, A.C.; Artaxo, P.; Balch, J.K.; Brown, I.F.; Bustamante, M.M.C.; Coe, M.T.; DeFries, R.S.; Keller, M.; Longo, M.; et al. The Amazon basin in transition. Nature 2012, 481, 321-328. [CrossRef] [PubMed]

47. Marlier, M.E.; DeFries, R.S.; Kim, P.S.; Koplitz, J.D.J.; Mickley, L.J.; Myers, S.S. Fire emissions and regional air quality impacts from fires in oil palm, timber, and logging concessions in Indonesia. Environ. Res. Lett. 2015, 10, 085005. [CrossRef]

48. Liu, T.J.; Marlier, M.E.; DeFries, R.S.; Westervelt, D.M.; Xia, K.R.; Flore, A.M.; Mickely, L.J.; Cusworth, D.H.; Milly, G. Seasonal impact of regional outdoor biomass burning on air pollution in three Indian cities: Delhi, Bengaluru, and Pune. Atmos. Environ. 2018, 172, 83-92. [CrossRef]

49. DeFries, R.S.; Nagendra, H. Ecosystem management as a wicked problem. Science 2017, 356, $265-270$. [CrossRef] [PubMed]

50. Millar, C.I.; Stephenson, N.L.; Stephens, S.L. Climate change and forests of the future: Managing in the face of uncertainty. Ecol. Appl. 2007, 17, 2145-2151. [CrossRef] [PubMed]

51. Millar, C.I.; Stephenson, N.L. Temperate forest health in an era of emerging megadisturbance. Science 2015, 349, 823-826. [CrossRef] [PubMed]

52. Millar, C.I.; Charlet, D.A.; Westfall, R.D.; King, J.C.; Delany, D.L.; Flint, A.L.; Flint, L.E. Do low-elevation ravines provide climate refugia for subalpine limber pine (Pinus flexilis) in the Great Basin, USA? Can. J. For. Res. 2018, 48, 663-671. [CrossRef]

53. Randerson, J.T.; Liu, H.; Flanner, M.G.; Chambers, S.D.; Jin, Y.; Hess, P.G.; Pfister, G.; Mack, M.C.; Treseder, K.K.; Welp, L.R.; et al. The impact of boreal forest fire on climate warming. Science 2006, 314, 1130-1132. [CrossRef] [PubMed] 
54. Harden, J.W.; Trumore, S.E.; Stocks, B.J.; Hirsh, A.; Gower, S.T.; O’Neill, K.P.; Kasishcke, E.S. The role of fire in the boreal carbon budget. Glob. Chang. Biol. 2000, 6, 174-184. [CrossRef]

55. Turetsky, M.R.; Kane, E.S.; Jarden, J.W.; Ottmar, R.D.; Manies, K.L.; Hoy, E.; Kasischke, E.S. Recent acceleration of biomass burning and carbon losses in Alaskan forests and peatlands. Nat. Geosci. 2011, 4, 27-31. [CrossRef]

56. Manies, K.L.; Harden, J.W.; Fuller, C.C.; Turetsky, M.R. Decadal and long-term boreal soil carbon and nitrogen sequestration rates across a variety of ecosystems. Biogeosciences 2016, 13, 4315-4327. [CrossRef]

57. Turner, M.G.; O'Neill, R.V.; Gardner, R.H.; Milne, B.T. Effects of changing spatial scale on the analysis of landscape pattern. Landsc. Ecol. 1989, 3, 153-162. [CrossRef]

58. Turner, M.G. Disturbance and landscape dynamics in a changing world. Ecology 2010, 91, $2833-2849$. [CrossRef] [PubMed]

59. Smithwick, E.A.H.; Turner, M.G.; Mack, M.C.; Chapin, F.S. Postfire soil N cycling in northern conifer forests affected by severe, stand-replacing wildfires. Ecosystems 2005, 8, 163-181. [CrossRef]

60. Turner, M.G.; Romme, W.H. Landscape dynamics in crown fire ecosystems. Landsc. Ecol. 1994, 9, 59-77. [CrossRef]

61. Turner, M.G.; Hargrove, W.W.; Gardner, R.H.; Romme, W.H. Effects of fire on landscape heterogeneity in Yellowstone National Park, Wyoming. J. Veg. Sci. 1994, 5, 731-742. [CrossRef]

62. Turner, M.G.; Romme, W.H.; Gardner, R.H.; Hargrove, W.W. Effects of fire size and pattern on early succession in Yellowstone National Park. Ecol. Monogr. 1997, 67, 411-433. [CrossRef]

63. Graves, R.A.; Pearson, S.M.; Turner, M.G. Species richness alone does not predict cultural ecosystem service value. Proc. Natl. Acad. Sci. USA 2017, 114, 3774-3779. [CrossRef] [PubMed]

64. Ziter, C.; Graves, R.A.; Turner, M.G. How do land-use legacies affect ecosystem services in United States cultural landscapes? Landsc. Ecol. 2017, 32, 2205-2218. [CrossRef]

65. Brown, P.M.; Sieg, C.H. Fire history in interior ponderosa pine communities of the Black Hills, South Dakota, USA. Int. J. Wildland Fire 1996, 6, 97-105. [CrossRef]

66. Brown, P.M.; Sieg, C.H. Historical variability in fire at the ponderosa pine-Northern Great Plains prairie ecotone, southeastern Black Hills, South Dakota. Ecoscience 1999, 6, 539-547. [CrossRef]

67. Owen, S.M.; Sieg, C.H.; Meador, A.J.S.; Fule, P.Z.; Iniguez, M.; Baggett, L.S.; Fornwalt, P.J.; Battaglia, M.A. Spatial patterns of ponderosa pine regeneration in high-severity burn patches. For. Ecol. Manag. 2017, 405, 134-149. [CrossRef]

68. Sieg, C.H.; Linn, R.R.; Pimont, F.; Hoffman, C.M.; McMillin, J.D.; Winterkamp, J.; Baggett, L.S. Fires following bark beetles: Factors controlling severity and disturbance interactions in ponderosa pine. Fire Ecol. 2017, 13, 1-23. [CrossRef]

69. Levine, J.M.; Vila, M.; D’Antonio, C.M.; Dukes, J.S.; Grigulis, K.; Lavorel, S. Mechanisms underlying the impacts of exotic plant invasions. Proc. R. Soc. B-Biol. Sci. 2003, 270, 775-781. [CrossRef] [PubMed]

70. Brooks, M.L.; D'Antonio, C.M.; Richardson, D.M.; Grace, J.B.; Keeley, J.E.; DiTomaso, J.M.; Hobbs, R.J.; Pellant, M.; Pyke, D. Effects of invasive alien plants on fire regimes. BioScience 2004, 54, 677-688. [CrossRef]

71. Mack, M.C.; D'Antonio, C.M. Impacts of biological invasions on disturbance regimes. Trends Ecol. Evol. 1998, 13, 195-198. [CrossRef]

72. Balch, J.K.; Bradley, B.A.; D'Antonio, C.M.; Gomez-Dans, J. Introduced annual grass increases regional fire activity across the arid western USA (1980-2009). Glob. Chang. Biol. 2013, 19, 173-183. [CrossRef] [PubMed]

73. D'Antonio, C.M.; Yelenik, S.G.; Mack, M.C. Ecosystem vs. community recovery 25 years after grass invasions and fire in a subtropical woodland. J. Ecol. 2017, 105, 1462-1474. [CrossRef]

74. Landres, P.B.; Morgan, P.; Swanson, F.J. Overview of the use of natural variability concepts in managing ecological systems. Ecol. Appl. 1999, 9, 1179-1188.

75. Morgan, P.; Hardy, C.C.; Swetnam, T.W.; Rollins, M.G.; Long, D.G. Mapping fire regimes across time and space: Understanding coarse and fine-scale fire patterns. Int. J. Wildland Fire 2001, 10, 329-342. [CrossRef]

76. Lentile, L.B.; Holden, Z.A.; Smith, A.M.S.; Falkowski, M.J.; Hudak, A.T.; Morgan, P.; Lewis, S.A.; Gessler, P.E.; Benson, N.C. Remote sensing techniques to assess active fire characteristics and post-fire effects. Int. J. Wildland Fire 2006, 15, 319-345. [CrossRef]

77. Morgan, P.; Hudak, A.T.; Wells, A.; Parks, S.A.; Baggett, L.S.; Bright, B.C.; Green, P. Multidecadal trends in area burned with high severity in the Selway-Bitterroot Wilderness Area 1880-2012. Int. J. Wildland Fire 2017, 26, 930-943. [CrossRef] 
78. Morgan, P. Strengthening syntheses on fire: Increasing their usefulness for managers. J. For. 2017, $115,141-142$.

79. Bachelet, D.; Neilson, R.P.; Lenihan, J.M.; Drapek, R.J. Climate change effects on vegetation distribution and carbon budget in the United States. Ecosystems 2001, 4, 164-185. [CrossRef]

80. Bachelet, D.; Neilson, R.P.; Hickler, T.; Drpaek, R.J.; Lenihan, J.M.; Sykes, M.T.; Smith, B.; Sitch, S.; Thonicke, K. Simulating past and future dynamics of natural ecosystems in the United States. Glob. Biogeochem. Cycle 2003, 17, 104. [CrossRef]

81. Allen, C.D.; Macalady, A.K.; Chenchouni, H.; Bachelet, D.; McDowell, N.; Vennetier, M.; Kitzberger, T.; Rigling, A.; Breshears, D.D.; Hogg, E.H.; et al. A global overview of drought and heat-induced tree mortality reveals emerging climate change risks for forests. For. Ecol. Manag. 2010, 259, 660-684. [CrossRef]

82. Bachelet, D.; Ferschweiler, K.; Sheehan, T.J.; Sleeter, B.M.; Zhu, Z. Projected carbon stocks in the conterminous USA with land use and variable fire regimes. Glob. Chang. Biol. 2015, 21, 4548-4560. [CrossRef] [PubMed]

83. Hantson, S.; Arneth, A.; Harrison, S.P.; Kelley, D.I.; Prentice, I.C.; Rabin, S.S.; Archibald, S.; Mouillot, F.; Arnold, S.R.; Artaxo, P.; et al. The status and challenge of global fire modelling. Biogeosciences 2016, 13, 3359-3375. [CrossRef]

84. Arthur, M.A.; Paratley, R.D.; Blankenship, B.A. Single and repeated fires affect survival and regeneration of woody and herbaceous species in an oak-pine forest. J. Torrey Bot. Soc. 1998, 125, 225-236. [CrossRef]

85. Lovett, G.M.; Weathers, K.C.; Arthur, M.A. Control of nitrogen loss from forested watersheds by soil carbon: Nitrogen ratio and tree species composition. Ecosystems 2002, 5, 712-718. [CrossRef]

86. Lovett, G.M.; Weathers, K.C.; Arthur, M.A.; Schultz, J.C. Nitrogen cycling in a northern hardwood forest: Do species matter? Biogeochemistry 2004, 67, 289-308. [CrossRef]

87. Arthur, M.A.; Blankenship, B.A.; Schorgendorfer, A.; Loftis, D.L.; Alexander, H.D. Changes in stand structure and tree vigor with repeated prescribed fire in an Appalachian hardwood forest. For. Ecol. Manag. 2015, 340, 46-61. [CrossRef]

88. Arthur, M.A.; Blankenship, B.A.; Schorgendorfer, A.; Alexander, H.D. Alterations to the fuel bed after single and repeated prescribed fires in an Appalachian hardwood forest. For. Ecol. Manag. 2017, 403, 126-136. [CrossRef]

89. Sala, A.; Piper, F.; Hoch, G. Physiological mechanisms of drought-induced tree mortality are far from being resolved. New Phytol. 2010, 186, 274-281. [CrossRef] [PubMed]

90. Anderegg, W.R.L.; Hicke, J.A.; Fischer, R.A.; Allen, C.D.; Aukema, J.; Bentz, B.; Hood, S.; Lichstein, J.W.; Macaldy, A.K.; McDowell, N.; et al. Tree mortality from drought, insects, and their interactions in a changing climate. New Phytol. 2015, 208, 674-683. [CrossRef] [PubMed]

91. Sala, A.; Woodruff, D.R.; Meinzer, F.C. Carbon dynamics in trees: Feast or famine? Tree Physiol. 2012, 32, 764-775. [CrossRef] [PubMed]

92. Dietz, M.C.; Sala, A.; Carbone, M.S.; Czimczik, C.I.; Mantooth, J.A.; Richardson, A.D.; Vargas, R. Nonstructural Carbon in Woody Plants. Ann. Rev. Plant Biol. 2014, 65, 667-687. [CrossRef] [PubMed]

93. Delcua, T.H.; Sala, A. Frequent fire alters nitrogen transformations in ponderosa pine stands of the inland northwest. Ecology 2006, 87, 2511-2522. [CrossRef]

94. De la Mata, R.; Hood, S.; Sala, A. Insect outbreak shifts the direction of selection from fast to slow growth rates in the long-lived conifer Pinus ponderosa. Proc. Natl. Acad. Sci. USA 2017, 114, 7391-7396. [CrossRef] [PubMed]

95. Hood, S.M.; Sala, A.; Heyerdahl, E.K.; Boutin, M. Low-severity fire increases tree defense against bark beetle attacks. Ecology 2015, 96, 1846-1855. [CrossRef] [PubMed]

96. Hood, S.M.; Stephen, B.; Sala, A. Fortifying the forest: Thinning and burning increase resistance to a bark beetle outbreak and promote forest resilience. Ecol. Appl. 2016, 26, 1984-2000. [CrossRef] [PubMed]

97. Vasconcelos, M.J.; Silva, S.; Tome, M.; Alvim, M.; Pereira, J.M.C. Spatial prediction of fire ignition probabilities: Comparing logistic regression and neural networks. Photogramm. Eng. Remote Sens. 2001, 67, 73-81.

98. Nunes, M.C.S.; Vasconcelos, M.J.; Pereira, J.M.C.; Dasgupta, N.; Alldredge, R.J.; Rego, F.C. Land cover type and fire in Portugal: Do fires burn land cover selectively? Landsc. Ecol. 2005, 20, 661-673. [CrossRef]

99. Cabral, A.I.R.; Silva, S.; Silva, P.C.; Vanneschi, L.; Vasconcelos, M.J. Burned area estimations derived from Landsat ETM+ and OLI data: Comparing Genetic Programming with Maximum Likelihood and Classification and Regression Trees. ISPRS J. Photogramm. Remote Sens. 2018, 142, 94-105. [CrossRef] 
100. Law, B.E.; Thornton, P.E.; Irvine, J.; Anthoni, P.M.; van Tuhl, S. Carbon storage and fluxes in ponderosa pine forests at different developmental stages. Glob. Chang. Biol. 2001, 7, 755-777. [CrossRef]

101. Law, B.E.; Turner, D.; Capmbell, J.; Sun, O.; van Tuhl, S.; Ritts, W.D.; Cohen, W.B. Disturbance and climate effects on carbon stocks and fluxes across Western Oregon USA. Glob. Chang. Biol. 2004, 10, 1429-1444. [CrossRef]

102. Magnami, F.; Mencuccini, M.; Borghetti, M.; Berbigler, P.; Berninger, F.; Delzon, S.; Grelle, A.; Harl, P.; Jarvis, P.G.; Kolari, P.; et al. The human footprint in the carbon cycle of temperate and boreal forests. Nature 2007, 447, 848-850.

103. Berner, L.T.; Law, B.E.; Meddens, A.J.H.; Hicke, J.A. Tree mortality from fires, bark beetles, and timber harvest during a hot and dry decade in the western United States (2003-2012). Environ. Res. Lett. 2017, 12, 065005. [CrossRef]

104. Law, B.E.; Hudiburg, T.W.; Berner, L.T.; Kent, J.J.; Buotte, P.C.; Harmon, M.E. Land use strategies to mitigate climate change in carbon dense temperate forests. Proc. Natl. Acad. Sci. USA 2018, 115, 3663-3668. [CrossRef] [PubMed]

105. Pivello, V.R.; Shida, C.N.; Meirelles, S.T. Alien grasses in Brazilian savannas: A threat to the biodiversity. Biodivers. Conserv. 1999, 8, 1281-1294.

106. Pivello, V.R. The use of Fire in the cerrado and Amazonian rainforests of Brazil: Past and present. Fire Ecol. 2011, 7, 24-39. [CrossRef]

107. Flchino, B.S.; Dombroski, J.R.G.; Pivello, V.R.; Fldelis, A. Does Fire Trigger Seed Germination in the Neotropical Savannas? Experimental Tests with Six Cerrado Species. Biotropica 2016, 48, 181-187. [CrossRef]

108. Soja, A.J.; Tchebakova, N.M.; French, N.H.F.; Flannigan, M.D.; Shugart, H.H.; Stocks, B.J.; Sukhinin, A.L.; Paftenova, E.L.; Chapin, F.S.; Stackhouse, P.W. Climate-induced boreal forest change: Predictions versus current observations. Glob. Planet. Chang. 2007, 56, 274-296. [CrossRef]

109. Kasischke, E.S.; French, N.H.F. Locating and estimating the areal extent of wildfire in Alaskan boreal forests using multiple-season AVHRR NDVI composite data. Remote Sens. Environ. 1995, 51, 263-275. [CrossRef]

110. French, N.H.F.; Kasichke, E.S.; Hall, R.J.; Murphy, K.A.; Verbyla, D.L.; Hoy, E.E.; Allen, J.L. Using Landsat data to assess fire and burn severity in the North American boreal forest region: An overview and summary of results. Int. J. Wildland Fire 2008, 17, 443-462. [CrossRef]

111. Zheng, T.; French, N.H.F.; Baxter, M. Development of the WRF-CO2 4D-Var assimilation system v1.0. Geosci. Model Dev. 2018, 11, 1725-1752. [CrossRef]

112. French, N.H.F.; Whittley, M.A.; Jenkins, L.K. Fire disturbance effects on land surface albedo in Alaskan tundra. J. Geophys. Res.-Biogeosci. 2016, 121, 841-854. [CrossRef]

113. Clark, R.L.; Jenkins, M.A.; Coen, J.; Packham, D. A coupled atmosphere-fire model: Convective feedback on fire-line dynamics. J. Appl. Meteorol. 1996, 35, 875-901. [CrossRef]

114. Clark, R.L.; Coen, J.; Latham, D. Description of a coupled atmosphere-fire model. Int. J. Wildland Fire 2004, 13, 49-63. [CrossRef]

115. Coen, J.L.; Schroeder, W. The High Park fire: Coupled weather-wildland fire model simulation of a windstorm-driven wildfire in Colorado's Front Range. J. Geophys. Res.-Atmos. 2015, 120, 131-146. [CrossRef]

116. Smith, P.; Bustamante, M.; Ahammad, H.; Clark, H.; Dong, H.M.; Elsiddig, E.A.; Haberl, H.; Harper, R.; House, J.; Jadari, M.; et al. Agriculture, Forestry and Other Land Use (AFOLU). In Climate Change 2014: Mitigation of Climate Change, Intergovernmental panel Climate Change, Working Group III; Edenhofer, O., Pichs-Madruga, R., Sokona, Y., Farahani, E., Kadner, S., Seyboth, K., Adler, A., Baum, I., Brunner, S., Eickemeier, P., et al., Eds.; Cambridge University Press: Cambridge, UK, 2014; pp. 811-922.

117. Bobbink, R.; Hicks, K.; Galloway, J.; Spranger, T.; Alkemade, R.; Ashmore, M.; Bustamante, M.; Cinderby, S.; Davidson, E.; Dentener, F.; et al. Global assessment of nitrogen deposition effects on terrestrial plant diversity: A synthesis. Ecol. Appl. 2010, 20, 30-59. [CrossRef] [PubMed]

118. Bustamante, M.M.C.; Roitman, I.; Aide, R.M.; Alencar, A.; Anderson, L.O.; Arago, L.; Asner, G.P.; Barlow, J.; Berenguer, E.; Chambers, J.; et al. Toward an integrated monitoring framework to assess the effects of tropical forest degradation and recovery on carbon stocks and biodiversity. Glob. Chang. Biol. 2016, 22, 92-109. [CrossRef] [PubMed]

119. Bell, T.L.; Pate, J.S. Growth and fire response of selected epacridaceae of south-western Australia. Australian J. Bot. 1996, 44, 509-526. [CrossRef] 
120. Bell, T.L.; Pate, J.S.; Dixon, K.W. Relationships between fire response, morphology, root anatomy and starch distribution in south-west Australian Epacridaceae. Ann. Bot. 1996, 77, 357-364. [CrossRef]

121. Gharun, M.; Possell, M.; Bell, T.L.; Adams, M.A. Optimisation of fuel reduction burning regimes for carbon, water and vegetation outcomes. J. Environ. Manag. 2017, 203, 157-170. [CrossRef] [PubMed]

122. Gharun, M.; Possell, M.; Vervoort, R.W.; Adams, M.S.; Bell, T.L. Can a growth model be used to describe forest carbon and water balance after fuel reduction burning in temperate forests? Sci. Total Environ. 2018, 615, 1000-1009. [CrossRef] [PubMed]

123. Chapin, F.S.; Zvaleta, E.S.; Eviner, V.T.; Naylor, R.L.; Vitousek, P.M.; Reynolds, H.L.; Hooper, D.U.; Lavorel, S.; Sala, O.E.; Hobbie, S.E.; et al. Consequences of changing biodiversity. Nature 2000, 405, 234-242. [CrossRef] [PubMed]

124. Mack, M.C.; Schuur, E.A.G.; Bret-Harte, M.S.; Shaver, G.R.; Chapin, F.S. Ecosystem carbon storage in arctic tundra reduced by long-term nutrient fertilization. Nature 2004, 431, 440-443. [CrossRef] [PubMed]

125. Mack, M.C.; Bret-Harte, M.S.; Hollingsworth, T.N.; Jandt, R.R.; Schuur, E.A.G.; Shaver, G.R.; Verbyla, D.L. Carbon loss from an unprecedented Arctic tundra wildfire. Nature 2011, 475, 489-492. [CrossRef] [PubMed]

126. Walker, X.J.; Mack, M.C.; Johnstone, J.F. Predicting Ecosystem Resilience to Fire from Tree Ring Analysis in Black Spruce Forests. Ecosystems 2017, 20, 1137-1150. [CrossRef]

127. Vlana, M.; Kuhlbusch, T.A.J.; Querol, X.; Alastuey, A.; Harrison, R.M.; Hopke, P.K.; Winlwarter, W.; Wallius, A.; Szidat, S.; Prevot, A.S.H.; et al. Source apportionment of particulate matter in Europe: A review of methods and results. J. Aerosol Sci. 2008, 39, 827-849.

128. Miranda, A.I.; Coutinho, M.; Borrego, C. Forest-fire emissions in Portugal-A contribution to global warming. Environ. Pollut. 1994, 83, 121-123. [CrossRef]

129. Miranda, A.I.; Borrego, C. A prognostic meteorological model applied to the study of a forest fire. Int. J. Wildland Fire 1996, 6, 157-163. [CrossRef]

130. Miranda, A.I. An integrated numerical system to estimate air quality effects of forest fires. Int. J. Wildland Fire 2004, 13, 217-226. [CrossRef]

131. Carvalho, A.; Flannigan, M.D.; Logan, K.; Maranda, A.I.; Borrego, C. Fire activity in Portugal and its relationship to weather and the Canadian Fire Weather Index System. Int. J. Wildland Fire 2008, 17, 328-338. [CrossRef]

132. Mok, K.M.; Miranda, A.I.; Yuen, K.V.; Hoi, K.I.; Monteiro, A.; Ribeiro, I. Selection of bias correction models for improving the daily PM10 forecasts of WRF-EURAD in Porto, Portugal. Atmos. Pollut. Res. 2017, 8, 628-639. [CrossRef]

133. Gama, C.; Monteiro, A.; Pio, C.; Miranda, A.I.; Baldasano, J.M.; Tchepel, O. Temporal patterns and trends of particulate matter over Portugal: A long-term analysis of background concentrations. Air Qual. Atmos. Health 2018, 11, 397-407. [CrossRef]

134. Andreae, M.O.; Rosenfeld, D.; Artaxo, P.; Costa, A.A.; Frank, G.P.; Longo, K.M.; Silva-Dias, M.A.F. Smoking rain clouds over the Amazon. Science 2004, 202, 1337-1342. [CrossRef] [PubMed]

135. Kaufman, Y.K.; Hobbs, P.V.; Kirchoff, V.W.J.H.; Artaxo, P.; Remer, L.A.; Holben, B.N.; King, M.D.; Ward, D.E.; Prins, E.M.; Longo, K.M.; et al. Smoke, clouds, and radiation-Brazil (SCAR-B) experiment. J. Geophys. Res. Atmos. 1998, 103, 31783-31808. [CrossRef]

136. Freitas, S.R.; Longo, K.M.; Chatfield, R.; Latham, D.; Silva-Dias, M.A.F.; Andreae, M.O.; Prins, E.; Santos, J.C.; Gielow, R.; Carvalho, J.R. Including the sub-grid scale plume rise of vegetation fires in low resolution atmospheric transport models. Atmos. Chem. Phys. 2007, 7, 3385-3398. [CrossRef]

137. Moreira, D.S.; Longo, K.M.; Freitas, S.R.; Yamasoe, L.N.; Roadario, N.E.; Gloor, E.; Viana, R.S.M.; Miller, J.B.; Gatti, L.V.; Wiedemann, K.T.; et al. Modeling the radiative effects of biomass burning aerosols on carbon fluxes in the Amazon region. Atmos. Chem. Phys. 2017, 17, 14785-14810.

138. Hodgson, A.K.; Morgan, W.; O'Shea, S.; Bauguitte, S.; Allan, J.D.; Darbyshire, E.; Flynn, M.J.; Liu, D.; Lee, J.; Johnson, B.; et al. Near-field emission profiling of tropical forest and Cerrado fires in Brazil during SAMBBA 2012. Atmos. Chem. Phys. 2018, 18, 5619-5638.

139. Hessl, A.E.; McKenzie, D.; Schellhaas, R. Drought and Pacific Decadal Oscillation linked to fire occurrence in the inland Pacific Northwest. Ecol. Appl. 2004, 14, 425-442. [CrossRef]

140. Heyerdahl, E.K.; McKenzie, D.; Daniels, L.D.; Hessl, A.E.; Little, J.S.; Mantua, N.J. Climate drivers of regionally synchronous fires in the inland Northwest (1651-1900). Int. J. Wildland Fire 2008, 17, 40-49. [CrossRef] 
141. Hessl, A.E.; Graumlich, L.J. Interactive effects of human activities, herbivory and fire on quaking aspen (Populus tremuloides) age structures in western Wyoming. J. Biogeogr. 2002, 29, 889-902. [CrossRef]

142. Hessl, A.E.; Brown, P.; Byambasuren, O.; Cockrell, S.; Leland, C.; Cook, E.; Bachin, B.; Pederson, N.; Saladyga, T.; Suran, B. Fire and climate in Mongolia (1532-2010 Common Era). Geophys. Res. Lett. 2016, 43, 6519-6527. [CrossRef]

143. Harley, G.L.; Baisan, C.H.; Brown, P.M.; Falk, D.A.; Flatley, W.T.; Grissino-Mayer, H.D.; Hessl, A.; Heyerdahl, E.K.; Kaye, M.W.; Lafon, C.W.; et al. Advancing Dendrochronological Studies of Fire in the United States. Fire 2018, 1, 11. [CrossRef]

144. Johnstone, J.F.; Chapin, F.S.; Hollingsworth, T.N.; Mack, M.C.; Romanovky, V.; Turetsky, M. Fire, climate change, and forest resilience in interior Alaska. Can. J. For. Res. 2010, 40, 1302-1312. [CrossRef]

145. Johnstone, J.F.; Hollingsworth, T.N.; Chapin, F.S.; Mack, M.C. Changes in fire regime break the legacy lock on successional trajectories in Alaskan boreal forest. Glob. Chang. Biol. 2010, 16, 1281-1295. [CrossRef]

146. Johnstone, J.F.; Kasischke, E.S. Stand-level effects of soil burn severity on postfire regeneration in a recently burned black spruce forest. Can. J. For. Res. 2004, 35, 2151-2163. [CrossRef]

147. Johnstone, J.F.; Chapin, F.S. Effects of soil burn severity on post-fire tree recruitment in boreal forest. Ecosystems 2006, 9, 14-31. [CrossRef]

148. Johnstone, J.F.; Allen, C.D.; Franklin, J.F.; Frelch, L.E.; Harvey, B.J.; Higuera, P.E.; Mack, M.C.; Meentemeyer, R.K.; Metz, M.R.; Perry, G.L.W.; et al. Changing disturbance regimes, ecological memory, and forest resilience. Front. Ecol. Environ. 2016, 14, 369-378. [CrossRef]

149. Bird, R.B.; Smith, E.A. Signaling theory, strategic interaction, and symbolic capital. Curr. Anthropol. 2005, 46, 221-248. [CrossRef]

150. Bird, D.W.; Bird, R.B.; Parker, C.H. Aboriginal burning regimes and hunting strategies in Australia's western desert. Human Ecol. 2005, 33, 443-464. [CrossRef]

151. Bird, R.B.; Bird, D.W.; Codding, B.F.; Parker, C.H.; Jones, J.H. The "fire stick farming" hypothesis: Australian Aboriginal foraging strategies, biodiversity, and anthropogenic fire mosaics. Proc. Natl. Acad. Sci. USA 2008, 105, 14796-14801. [CrossRef] [PubMed]

152. Bird, R.B.; Codding, B.F.; Kauhanen, P.G.; Bird, D.W. Aboriginal hunting buffers climate-driven fire-size variability in Australia's spinifex grasslands. Proc. Natl. Acad. Sci. USA 2012, 109, 10287-10292. [CrossRef] [PubMed]

153. Bird, R.B.; Bird, D.W.; Fernandez, L.E.; Taylor, N.; Taylor, W.; Nimmo, D. Aboriginal burning promotes fine-scale pyrodiversity and native predators in Australia's Western Desert. Biol. Conserv. 2018, 219, 110-118. [CrossRef]

154. Bird, R.B.; Bird, D.W.; Codding, B.R. People, El Nino southern oscillation and fire in Australia: Fire regimes and climate controls in hummock grasslands. Phil. Trans. R. Soc. B-Biol. Sci. 2016, 371, 20150343. [CrossRef] [PubMed]

155. Steelman, T.A.; Ascher, W. Public involvement methods in natural resource policy making: Advantages, disadvantages and trade-offs. Policy Sci. 1997, 30, 71-90. [CrossRef]

156. Steelman, T.A.; Maguire, L.A. Understanding participant perspectives: Q-nethodology in National Forest Management. J. Pol. Anal. Manag. 1999, 18, 361-388. [CrossRef]

157. Steelman, T.A.; McCaffrey, S.M.; Velez, A.L.K.; Briefel, J.A. What information do people use, trust, and find useful during a disaster? Evidence from five large wildfires. Nat. Hazards 2015, 76, 615-634. [CrossRef]

158. Krawchuk, M.A.; Moritz, M.A.; Parlslen, M.A.; Van Dorn, J.; Hayhoe, K. Global Pyrogeography: The Current and Future Distribution of Wildfire. PLoS ONE 2009, 4, e5102. [CrossRef] [PubMed]

159. Krawchuk, M.A.; Cumming, S.G.; Flannigan, M.D.; Wein, R.W. Biotic and abiotic regulation of lightning fire initiation in the mixedwood boreal forest. Ecology 2006, 87, 458-468. [CrossRef] [PubMed]

160. Krawchuk, M.A.; Moritz, M.A. Constraints on global fire activity vary across a resource gradient. Ecology 2011, 92, 121-132. [CrossRef] [PubMed]

161. Krawchuk, M.A.; Haire, S.L.; Coop, J.; Parisien, M.A.; Whitman, E.; Chong, G.; Miller, C. Topographic and fire weather controls of fire refugia in forested ecosystems of northwestern North America. Ecosphere 2016, 7, e01632. [CrossRef]

162. Camp, P.E.; Krawchuk, M.A. Spatially varying constraints of human-caused fire occurrence in British Columbia, Canada. Int. J. Wildland Fire 2017, 26, 219-229. [CrossRef] 
163. Meigs, G.W.; Krawchuk, M.A. Composition and Structure of Forest Fire Refugia: What Are the Ecosystem Legacies across Burned Landscapes? Forests 2018, 9, 243. [CrossRef]

164. Johnston, F.H.; Kavanagh, A.M.; Bowman, D.M.J.S.; Scott, R.K. Exposure to bushfire smoke and asthma: An ecological study. Med. J. Austral. 2002, 176, 535-538. [PubMed]

165. Johnston, F.H.; Bailie, R.S.; Pilotto, L.S.; Hanigan, I.C. Ambient biomass smoke and cardio-respiratory hospital admissions in Darwin, Australia. BMC Public Health 2007, 7, 240. [CrossRef] [PubMed]

166. Johnston, F.H.; Henderson, S.B.; Chen, Y.; Randerson, J.T.; Marlier, M.; DeFries, R.S.; Kinney, P.; Bowman, D.M.J.S.; Brauer, M. Estimated global mortality attributed to smoke from landscape fires. Environ. Health Perspect. 2012, 120, 695-701. [CrossRef] [PubMed]

167. Horsley, J.A.; Broome, R.A.; Johnston, F.H.; Cope, M.; Morgan, G.G. Health burden associated with fire smoke in Sydney, 2001-2013. Med. J. Austral. 2018, 208, 309-310. [CrossRef] [PubMed]

168. Johnston, F.H.; Wheeler, A.J.; Williamson, G.J.; Campbell, S.L.; Jones, P.J.; Koolhof, L.S.; Lucani, C.; Cooling, N.B.; Bowman, D.M.J.S. Using smartphone technology to reduce health impacts from atmospheric environmental hazards. Environ. Res. Lett. 2018, 13, 044019. [CrossRef]

169. Van der Werf, G.R.; Randerson, H.T.; Giglio, K.; Collatz, G.J.; Mu, M.; Kasibhalta, P.S.; Morton, D.C.; DrFries, R.S.; Jin, Y.; van Leeuwen, T.T. Global fire emissions and the contribution of deforestation, savanna, forest, agricultural, and peat fires (1997-2009). Atmos. Chem. Phys. 2010, 10, 11707-11735. [CrossRef]

170. Jin, Y.F.; Randerson, J.T.; Goetz, S.J.; Beck, P.S.A.; Loranty, M.M.; Goulden, M.L. The influence of burn severity on postfire vegetation recovery and albedo change during early succession in North American boreal forests. J. Geophys. Res.-Biogeosci. 2012, 117, G01036. [CrossRef]

171. Jin, Y.F.; Goulden, M.L.; Faivre, N.; Veraverbeke, S.; Sun, F.P.; Hall, A.; Hand, M.S.; Hook, S.; Randerson, J.T. Identification of two distinct fire regimes in Southern California: Implications for economic impact and future change. Environ. Res. Lett. 2015, 10, 094005. [CrossRef]

172. Jin, Y.F.; Randerson, J.T.; Faivre, N.; Capps, S.; Hall, A.; Goulden, M.L. Contrasting controls on wildland fires in Southern California during periods with and without Santa Ana winds. J. Geophys. Res.-Biogeosci. 2014, 119, 432-450. [CrossRef]

173. McLauchlan, K.K.; Williams, J.J.; Craine, J.M. Changes in global nitrogen cycling during the Holocene epoch. Nature 2013, 495, 352-355. [CrossRef] [PubMed]

174. McLauchlan, K.K.; Higuera, P.E.; Gavin, D.G.; Perakis, S.S.; Mack, M.C.; Alexander, H.; Battles, J.; Blondi, F.; Buma, B.; Colombararoli, D.; et al. Reconstructing Disturbances and Their Biogeochemical Consequences over Multiple Timescales. BioScience 2014, 64, 105-116. [CrossRef]

175. Leys, B.A.; Commerford, J.L.; McLauchlan, K.K. Reconstructing grassland fire history using sedimentary charcoal: Considering count, size and shape. PLOS ONE 2017, 12, e0176445.

176. Daniels, L.D.; Veblen, T.T. Spatiotemporal influences of climate on altitudinal treeline in northern Patagonia. Ecology 2014, 85, 1284-1296. [CrossRef]

177. Van Mantgrem, P.J.; Stephenson, N.L.; Burne, J.C.; Daniels, L.D.; Franklin, J.F.; Fule, P.Z.; Harmon, M.E.; Larson, A.J.; Smith, J.M.; Taylor, A.H.; et al. Widespread Increase of Tree Mortality Rates in the Western United States. Science 2009, 323, 521-524. [CrossRef] [PubMed]

178. Chavardes, R.D.; Daniels, L.D.; Gedalof, Z.; Andison, D.W. Human influences superseded climate to disrupt the 20th century fire regime in Jasper National Park, Canada. Dendrochronologia 2018, 48, 10-19. [CrossRef]

179. Greene, G.A.; Daniels, L.D. Spatial interpolation and mean fire interval analyses quantify historical mixed-severity fire regimes. Int. J. Wildland Fire 2017, 26, 136-147. [CrossRef]

180. Hély, C.; Bergeron, Y.; Flannigan, M.D. Effects of stand composition on fire hazard in mixed-wood Canadian boreal forest. J. Veg. Sci. 2000, 11, 813-824. [CrossRef]

181. Hély, C.; Flannigan, M.; Vergeron, Y.; McRae, D. Role of vegetation and weather on fire behavior in the Canadian mixedwood boreal forest using two fire behavior prediction systems. Can. J. For. Res. 2001, 31, 430-441. [CrossRef]

182. Hély, C.; Girardin, M.P.; Ali, A.A.; Carcaillet, C.; Brewer, S.; Bergeron, Y. Eastern boreal North American wildfire risk of the past 7000 years: A model-data comparison. Geophys. Res. Lett. 2010, 37, L14709. [CrossRef]

183. Hély, C.; Lézine, A.-M. Holocene changes in African vegetation; tradeoff between climate and water availability. Clim. Past 2014, 10, 681-686. [CrossRef]

184. Laheye, S.; Curt, T.; Fréjaville, S.; Paradis, J.; Hély, C. What are the drivers of dangerous fires in Mediterranean France? Int. J. Wildland Fire 2018, 27, 155-163. [CrossRef] 
185. Parr, C.L.; Anderson, A.N. Patch Mosaic Burning for Biodiversity Conservation: A Critique of the Pyrodiversity Paradigm. Conserv. Biol. 2006, 20, 1610-1619. [CrossRef] [PubMed]

186. Parr, C.L.; Robertson, H.G.; Biggs, H.C.; Chown, S.L. Response of African savanna ants to long-term fir regimes. J. Appl. Ecol. 2004, 41, 630-642. [CrossRef]

187. Parr, C.L.; Lehmann, C.E.R.; Bond, W.J.; Hoffman, W.A.; Andersen, A.N. Tropical grassy biomes: Misunderstood, neglected, and under threat. Trends Ecol. Evol. 2014, 29, 205-213. [CrossRef] [PubMed]

188. Pausas, J.G.; Parr, C.L. Towards an understanding of the evolutionary role of fire in animals. Evol. Ecol. 2018, 32, 113-125. [CrossRef]

189. Falk, D.A.; Miller, C.; McKenzie, D.; Black, A.E. Cross-scale analysis of fire regimes. Ecosystems 2007, 10, 809-823. [CrossRef]

190. Miller, C.; Ager, A.A. A review of recent advances in risk analysis for wildfire management. Int. J. Wildand Fire 2013, 22, 1-14. [CrossRef]

191. Haire, S.L.; Coop, J.D.; Miller, C. Characterizing Spatial Neighborhoods of Refugia Following Large Fires in Northern New Mexico USA. Land 2017, 6, 19. [CrossRef]

192. Miller, C.; Aplet, G.H. Progress in Wilderness Fire Science: Embracing Complexity. J. For. 2016, 114, $373-383$. [CrossRef]

193. Schoennagel, T.; Veblen, T.T.; Romme, W.H. The Interaction of fire, fuels, and climate across Rocky Mountain forests. BioScience 2004, 54, 661-676. [CrossRef]

194. Schoennagel, T.; Veblen, T.T.; Romme, W.H.; Sibold, J.S.; Cook, E.R. Enso and pdo variability affect drought-induced fire occurrence in Rocky Mountain subalpine forests. Ecol. Appl. 2005, 15, 2000-2014. [CrossRef]

195. Schoennagel, T.; Nelson, C.R.; Theobald, D.M.; Carnwath, G.C.; Chapman, T.B. Implementation of National Fire Plan treatments near the wildland-urban interface in the western United States. Proc. Natl. Acad. Sci. USA 2009, 106, 10706-10711. [CrossRef] [PubMed]

196. Moritz, M.A.; Bartllori, E.; Bradstock, R.A.; Gill, A.M.; Handmer, J.; Hessburg, P.F.; Leonard, J.; McCaffrey, S.; Odion, D.C.; Schoennagel, T.; et al. Learning to coexist with wildfire. Nature 2014, 515, 58-66. [CrossRef] [PubMed]

197. Armenteras, D.; Ruda, G.; Rodriguez, N.; Sua, S.; Romero, M. Patterns and causes of deforestation in the Colombian Amazon. Ecol. Indic. 2006, 6, 353-368. [CrossRef]

198. Armenteras, D.; Gonzalez, T.M.; Retana, J. Forest fragmentation and edge influence on fire occurrence and intensity under different management types in Amazon forests. Biol. Conserv. 2013, 159, 73-79. [CrossRef]

199. Armenteras, D.; Barreto, J.S.; Tabor, K.; Molowny-Horas, R.; Retana, J. Changing patterns of fire occurrence in proximity to forest edges, roads and rivers between NW Amazonian countries. Biogeosciences 2017, 14, 2755-2765. [CrossRef]

200. Armenteras, D.; Gibbes, C.; Aaya, J.A.; Davalos, L.M. Integrating remotely sensed fires for predicting deforestation for REDD. Ecol. Appl. 2017, 27, 1294-1304. [CrossRef] [PubMed]

201. Nepstad, D.C.; Verissimo, A.; Alencar, A.; Nobre, C.; Lime, E.; Lefebvre, P.; Schlessinger, P.; Potter, C.; Moutinho, P.; Mendoza, E.; et al. Large-scale impoverishment of Amazonian forests by logging and fire. Nature 1999, 398, 505-508. [CrossRef]

202. Cochrane, M.A.; Alencar, A.; Schluze, M.S.; Souza, C.M.; Nepstad, D.C.; Lefebvre, P.; Davidson, E.A. Positive feedbacks in the fire dynamic of closed canopy tropical forests. Science 1999, 284, 1832-1835. [CrossRef] [PubMed]

203. Azevedo, A.A.; Rajo, R.; Costa, M.A.; Stabile, M.C.C.; Macedo, M.N.; do Reis, T.N.P.; Alencar, A.; Soares-Fihlo, B.S.; Pacheco, R. Limits of Brazil's Forest Code as a means to end illegal deforestation. Proc. Natl. Acad. Sci. USA 2017, 114, 7653-7658. [CrossRef] [PubMed]

204. Guenther, A.; Karl, T.; Harley, P.; Wiedinmyer, C.; Palmer, P.I.; Geron, C. Estimates of global terrestrial isoprene emissions using MEGAN (Model of Emissions of Gases and Aerosols from Nature). Atmos. Chem. Phys. 2006, 6, 3181-3210. [CrossRef]

205. Wiedinmyer, C.; Akago, S.K.; Yokelson, R.J.; Emmons, L.K.; Al-Saadi, J.A.; Orlando, J.J.; Soja, A.J. The Fire INventory from NCAR (FINN): A high resolution global model to estimate the emissions from open burning. Geosci. Model Dev. 2011, 4, 625-641. [CrossRef] 
206. Wiedinmyer, C.; Quale, B.; Geron, C.; Belote, A.; McKenzie, D.; Xhang, X.Y.; O’Neill, S.; Wynne, K.K. Estimating emissions from fires in North America for air quality modeling. Atmos. Environ. 2006, 40, 3419-3432. [CrossRef]

207. Thomas, J.L.; Polashenski, C.M.; Soja, A.J.; Marelle, L.; Casey, K.A.; Choi, H.D.; Raut, J.-C.; Wiedinmyer, C.; Emmos, L.K.; Fast, J.D.; et al. Quantifying black carbon deposition over the Greenland ice sheet from forest fires in Canada. Geophys. Res. Lett. 2017, 44, 7965-7974. [CrossRef]

208. Syphard, A.D.; Radeloff, V.C.; Keeley, J.E.; Hawbaker, T.J.; Clayton, M.K.; Stewart, S.I.; Hammer, R.B. Human influence on California fire regimes. Ecol. Appl. 2007, 17, 1388-1402. [CrossRef] [PubMed]

209. Syphrad, A.D.; Radeloff, V.C.; Keuler, N.S.; Taylor, R.S.; Hawbaker, T.J.; Stewart, S.I.; Clayton, M.K. Predicting spatial patterns of fire on a southern California landscape. Int. J. Wildland Fire 2008, 17, 602-613. [CrossRef]

210. Radeloff, V.C.; Helmers, D.P.; Kramer, H.A.; Mockrin, M.H.; Alexandre, P.M.; Bar-Massada, A.; Bustic, V.; Hawbaker, T.J.; Martinuzzo, S.; Syphard, A.D.; et al. Rapid growth of the US wildland-urban interface raises wildfire risk. Proc. Natl. Acad. Sci. USA 2018, 115, 3314-3319. [CrossRef] [PubMed]

211. Trouet, V.; Taylor, A.H.; Carleton, A.M.; Skinner, C.N. Fire-climate interactions in forests of the American Pacific coast. Geophys. Res. Lett. 2006, 33, L18704. [CrossRef]

212. Trouet, V.; Taylor, A.H.; Wahl, E.R.; Skinner, C.N.; Stephens, S.L. Fire-climate interactions in the American West since 1400 CE. Geophys. Res. Lett. 2010, 37, L04702. [CrossRef]

213. Trouet, V.; Esper, J.; Graham, N.E.; Baker, A.; Scourse, J.D.; Frank, D.C. Persistent Positive North Atlantic Oscillation Mode Dominated the Medieval Climate Anomaly. Science 2009, 324, 78-80. [CrossRef] [PubMed]

214. Taylor, A.H.; Trouet, V.; Skinner, C.N.; Stephens, S. Socioecological transitions trigger fire regime shifts and modulate fire-climate interactions in the Sierra Nevada, USA, 1600-2015 CE. Proc. Natl. Acad. Sci. USA 2016, 113, 13684-13689. [CrossRef] [PubMed]

215. Alfaro-Sanchez, R.; Camarero, J.J.; Sanchez-Salhuero, R.; Trouet, V.; Heras, J.D. How do droughts and wildfires alter season radial growth in Mediterranean Allepo pine forests? Tree-Ring Res. 2018, 74, 1-14. [CrossRef]

216. Kuligowski, E.D. Predicting human behavior during fires. Fire Technol. 2013, 40, 101-120. [CrossRef]

217. Kuligowski, E.D.; Gwynne, S.M.V.; Kinsey, M.J.; Hulse, L. Guidance for the Model User on Representing Human Behavior in Egress Models. Fire Technol. 2017, 53, 649-672. [CrossRef] [PubMed]

218. Heyerdahl, E.K.; Brubaker, L.B.; Agee, J.K. Spatial controls of historical fire regimes: A multiscale example from the interior west, USA. Ecology 2001, 82, 660-678. [CrossRef]

219. Heyerdahl, E.K.; Brubaker, L.B.; Agee, J.K. Annual and decadal climate forcing of historical fire regimes in the interior Pacific Northwest, USA. Holocene 2002, 12, 597-604. [CrossRef]

220. Heyerdahl, E.K.; Mckay, S.J. Condition of live fire-scarred ponderosa pine twenty-one years after removing partial cross-sections. Tree-Ring Res. 2017, 73, 149-153. [CrossRef]

221. Turner, M.G.; Smithwick, E.A.H.; Metzger, K.L.; Tinker, D.B.; Romme, W.H. Inorganic nitrogen availability after severe stand-replacing fire in the Greater Yellowstone ecosystem. Proc. Natl. Acad. Sci. USA 2007, 104, 4782-4789. [CrossRef] [PubMed]

222. Smithwick, E.A.H.; Harmon, M.E.; Remillard, S.; Acker, S.A.; Franklin, F.J. Potential upper bounds of carbon stores in forests of the Pacific Northwest. Ecol. Appl. 2002, 12, 1303-1317. [CrossRef]

223. Smithwick, E.A.H. Pyrogeography: Build social costs into wildfire risk. Nature 2016, 535, 231. [CrossRef] [PubMed]

224. Archibald, S.; Bond, W.J.; Stock, W.D.; Fairbanks, D.H.K. Shaping the landscape: Fire-grazer interactions in an African savanna. Ecol. Appl. 2005, 15, 96-109. [CrossRef]

225. Staver, A.C.; Archibald, S.; Levin, S.A. The Global Extent and Determinants of Savanna and Forest as Alternative Biome States. Science 2011, 334, 230-232. [CrossRef] [PubMed]

226. Lehmann, C.E.R.; Anderson, T.M.; Sankaran, M.; Higgins, S.I.; Archibald, S.; Hoffmann, W.A.; Hanan, N.P.; Williams, R.J.; Fensham, R.J.; Felfili, J.; et al. Savanna vegetation-fire-climate relationships differ among continent. Science 2014, 343, 548-552. [CrossRef] [PubMed]

227. Archibald, S.; Hempsoon, G.P. Competing consumers: Contrasting the patterns and impacts of fire and mammalian herbivory in Africa. Phil. Trans. R. Soc. B-Biol. Sci. 2016, 371. [CrossRef] [PubMed]

228. Archibald, S.; Roy, D.P.; van Wilgen, B.W.; Scholes, R.J. What limits fire? An examination of drivers of burnt area in Southern Africa. Glob. Chang. Biol. 2009, 15, 613-630. [CrossRef] 
229. Archibald, S. Managing the human component of fire regimes: Lessons from Africa. Phil. Trans. R. Soc. B-Biol. Sci. 2016, 371, 20150346. [CrossRef] [PubMed]

230. Archibald, S.; Lehmann, C.E.R.; Belcher, C.M.; Bond, W.J.; Bradstock, R.A.; Daniau, A.L.; Dexter, K.G.; Forrestel, E.J.; Greve, M.; He, T.; et al. Biological and geophysical feedbacks with fire in the Earth system. Environ. Res. Lett. 2018, 13, 033003. [CrossRef]

231. Marlon, J.R.; Bartlein, P.J.; Carcaillet, C.; Gavin, D.G.; Harrison, S.P.; Higuera, P.E.; Joos, F.; Power, M.J.; Prentice, I.C. Climate and human influences on global biomass burning over the past two millennia. Nat. Geosci. 2008, 1, 697-702. [CrossRef]

232. Marlon, J.R.; Bartlein, P.J.; Gavin, D.G.; Long, C.J.; Anderson, R.S.; Briles, C.E.; Brown, K.J.; Colombaroli, D.; Hallet, D.J.; Power, M.J.; et al. Long-term perspective on wildfires in the western USA. Proc. Natl. Acad. Sci. USA 2012, 109, E535-E543. [CrossRef] [PubMed]

233. Marlon, J.R.; Bartlein, P.J.; Walsh, M.K.; Harrison, S.P.; Brown, K.J.; Edwards, M.E.; Higuera, P.E.; Power, M.J.; Anderson, R.S.; Briles, C.; et al. Wildfire responses to abrupt climate change in North America. Proc. Natl. Acad. Sci. USA 2009, 106, 2519-2524. [CrossRef] [PubMed]

234. Marlon, J.R.; Kelly, R.; Daniau, A.L.; Vanniere, B.; Power, M.J.; Bartlein, P.; Higuera, P.E.; Blarquez, O.; Brewer, S.; Brucher, T. Reconstructions of biomass burning from sediment-charcoal records to improve data-model comparisons. Biogeosciences 2016, 13, 3225-3244. [CrossRef]

235. Overbeck, G.E.; Muller, S.C.; Fidelis, A.; Pfadenhauer, J.; Pillar, V.D.; Blanco, C.C.; Boldrini, I.I.; Both, R.; Forneck, E.D. Brazil's neglected biome: The South Brazilian Campos. Perspect. Plant Ecol. Evol. Syst. 2007, 9, 101-116. [CrossRef]

236. Rissi, M.N.; Baeza, M.; Gorgone, J.; Barbosa, E.; Zupo, T.; Fidelis, A. Does season affect fire behaviour in the Cerrado? Int. J. Wildland Fire 2017, 26, 427-433.

237. Schmidt, I.B.; Fidelis, A.; Miranda, H.S.; Ticktin, T. How do the wets burn? Fire behavior and intensity in wet grasslands in the Brazilian savanna. Braz. J. Bot. 2017, 40, 167-175. [CrossRef]

238. Belcher, C.M. (Ed.) Fire Phenomena and the Earth System: An Interdisciplinary Guide to Fire Science; Wiley-Blackwell: Oxford, UK, 2013; p. 350.

239. Belcher, C.M.; McElwain, J.C. Limits for combustion in low $\mathrm{O}_{2}$ redefine paleoatmospheric predictions for the Mesozoic. Science 2008, 321, 1197-1200. [CrossRef] [PubMed]

240. Belcher, C.M.; Yearsley, J.M.; Haddem, R.M.; McElwain, J.C.; Guillermo, R. Baseline intrinsic flammability of Earth's ecosystems estimated from paleoatmospheric oxygen over the past 350 million years. Proc. Natl. Acad. Sci. USA 2010, 107, 22448-22453. [CrossRef] [PubMed]

241. McCaffrey, S.; Toman, E.; Stidham, M.; Shindler, B. Social science research related to wildfire management: An overview of recent findings and future research needs. Int. J. Wildland Fire 2014, 22, 15-24. [CrossRef]

242. McCaffrey, S. Community Wildfire Preparedness: A Global State-of-the-Knowledge Summary of Social Science Research. Curr. For. Rep. 2015, 1, 81-90. [CrossRef]

243. Loboda, T.V.; Csiszar, I.A. Assessing the risk of ignition in the Russian Far East within a modeling framework of fire threat. Ecol. Appl. 2007, 17, 791-805. [CrossRef] [PubMed]

244. Hall, J.; Loboda, T. Quantifying the Potential for Low-Level Transport of Black Carbon Emissions from Cropland Burning in Russia to the Snow-Covered Arctic. Front. Earth Sci. 2017, 5. [CrossRef]

245. Hall, J.; Loboda, T. Quantifying the variability of potential black carbon transport from cropland burning in Russia driven by atmospheric blocking events. Environ. Res. Lett. 2018, 13, 055010. [CrossRef]

246. Bradley, B.A.; Blumenthal, S.M.; Wilcove, D.S.A.; Ziska, L.H. Predicting plant invasions in an era of global change. Trend. Ecol. Evol. 2010, 25, 310-318. [CrossRef] [PubMed]

247. Bradley, B.A.; Mustard, J.F. Characterizing the landscape dynamics of an invasive plant and risk of invasion using remote sensing. Ecol. Appl. 2006, 16, 1132-1147. [CrossRef]

248. Bradley, B.A.; Curtis, C.A.; Fusco, W.J.; Abatzoglou, J.T.; Balch, J.T.; Dadashi, S.; Tuanmu, M.N. Cheatgrass (Bromus tectorum) distribution in the intermountain Western United States and its relationship to fire frequency, seasonality, and ignitions. Biol. Invas. 2018, 20, 1493-1506. [CrossRef]

249. Nagy, R.C.; Fusco, E.; Bradley, B.; Abatzoglou, J.T.; Balch, J.K. Huma-related ignitions increase the number of large wildfires across U.S. ecoregions. Fire 2018, 1, 4. [CrossRef]

250. Abatzoglou, J.T.; Balch, J.K.; Bradley, B.A.; Kolden, C.A. Human-related ignitions concurrent with high winds promote large wildfires across the USA. Int. J. Wildland Fire 2018, 27, 377-386. [CrossRef] 
251. Bajocco, S.; Carlo, R. Evidence of selective burning in Sardinia (Italy): Which land-cover classes do wildfires prefer? Landsc. Ecol. 2008, 23, 241-248. [CrossRef]

252. Salvati, L.; Bajocco, S. Land sensitivity to desertification across Italy Past, present, and future. Appl. Geogr. 2011, 31, 223-231. [CrossRef]

253. Bajocco, S.; Koutsias, N.; Ricotta, C. Linking fire ignitions hotspots and fuel phenology: The importance of being seasonal. Ecol. Indic. 2017, 82, 433-440. [CrossRef]

254. Bajocco, S.; Dragoz, E.; Gitas, I.; Smieraglia, D.; Salvato, L.; Riccota, C. Mapping Forest Fuels through Vegetation Phenology: The Role of Coarse-Resolution Satellite Time-Series. PLoS ONE 2015, 10, e0119811. [CrossRef] [PubMed]

255. Charnley, S.; Fischer, A.P.; Jones, E.T. Integrating traditional and local ecological knowledge into forest biodiversity conservation in the Pacific Northwest. For. Ecol. Manag. 2007, 246, 14-28. [CrossRef]

256. Spies, T.A.; White, E.M.; Kline, J.D.; Fischer, A.P.; Ager, A.; Bailey, J.; Bolte, J.; Koch, J.; Platt, E.; Olson, C.S.; et al. Examining fire-prone forest landscapes as coupled human and natural systems. Ecol. Soc. 2014, 19, 9. [CrossRef]

257. Henderson, S.B.; Brauer, M.; MacNab, Y.C.; Kennedy, S.M. Three Measures of Forest Fire Smoke Exposure and Their Associations with Respiratory and Cardiovascular Health Outcomes in a Population-Based Cohort. Environ. Health Perspect. 2011, 119, 1266-1271. [CrossRef] [PubMed]

258. Yao, J.Y.; Raffuse, S.M.; Brauer, M.; Williamson, G.J.; Bowman, D.M.J.S.; Johnston, F.H.; Henderson, S.B. Predicting the minimum height of forest fire smoke within the atmosphere using machine learning and data from the CALIPSO satellite. Remote Sens. Environ. 2018, 206, 98-106. [CrossRef]

259. Williamson, G.J.; Bowman, D.M.J.S.; Price, O.F.; Henderson, S.B.; Johnston, F.H. A transdisciplinary approach to understanding the health effects of wildfire and prescribed fire smoke regimes. Environ. Res. Lett. 2016, 11, 125009. [CrossRef]

260. Balch, J.K.; Depstad, D.; Brando, P.; Curran, L.M.; Portela, O.; de Carvalho, O.; Lefebvre, P. Negative fire feedback in a transitional forest of southeastern Amazonia. Glob. Chang. Biol. 2008, 14, 2276-2287. [CrossRef]

261. Balch, J.K.; Schoennagel, T.; Williams, A.P.; Abatzoglou, J.T.; Cattau, M.E.; Mietkiewicz, N.P.; St Dennis, L.A. Switching on the Big Burn of 2017. Fire 2018, 1, 17. [CrossRef]

262. Abatzoglou, J.T.; Kolden, C.A. Relationships between climate and macroscale area burned in the western United States. Int. J. Wildland Fire 2013, 22, 1003-1020. [CrossRef]

263. Kolden, C.A.; Lutz, J.A.; Key, C.H.; Kane, J.T.; van Wagtendonk, J.W. Mapped versus actual burned area within wildfire perimeters: Characterizing the unburned. For. Ecol. Manag. 2012, 286, 38-47. [CrossRef]

264. Kolden, C.A.; Bleeker, T.M.; Smith, A.M.S.; Poulos, H.M.; Camp, A.E. Fire Effects on Historical Wildfire Refugia in Contemporary Wildfires. Forests 2017, 8, 400. [CrossRef]

265. Kolden, C.A.; Abatzoglou, J.T. Spatial distribution of wildfires ignited under katabatic versus non-katabatic winds in Mediterranean south California USA. Fire 2018, 1, 19. [CrossRef]

266. Lehmann, C.E.R.; Archibald, S.A.; Hoffman, W.A.; Bond, W.J. Deciphering the distribution of the savanna biome. New Phytol. 2011, 191, 197-209. [CrossRef] [PubMed]

267. Stevens, N.; Lehmann, C.E.R.; Murphy, B.P.; Durigan, G. Savanna woody encroachment is widespread across three continents. Glob. Chang. Biol. 2017, 23, 235-244. [CrossRef] [PubMed]

268. Hood, S.M.; Bentz, B. Predicting postfire Douglas-fir beetle attacks and tree mortality in the northern Rocky Mountains. Can. J. For. Res. 2007, 37, 1058-1069. [CrossRef]

269. Grayson, L.M.; Progar, R.A.; Hood, S.M. Predicting post-fire tree mortality for 14 conifers in the Pacific Northwest, USA: Model evaluation, development, and thresholds. Forest Ecol. Manag. 2017, 399, 213-226. [CrossRef]

270. Clyatt, K.A.; Keyes, C.R.; Hood, S.M. Long-term effects of fuel treatments on aboveground biomass accumulation in ponderosa pine forests of the northern Rocky Mountains. Forest Ecology and Management. Forest Ecol. Manag. 2017, 400, 587-599. [CrossRef]

271. Albini, F.A.; Reinhardt, E.D. Modeling ignition and burning rate of large woody natural fuels. Int. J. Wildland Fire 1995, 5, 81-91. [CrossRef]

272. Ryan, K.C.; Reinhardt, E.D. Predicting post-fire mortality of 7 western conifers. Can. J. For. Res. 1988, 18, 1291-1297. [CrossRef]

273. Reinhardt, E.D.; Keane, R.E.; Brown, J.K. Modelling fire effects. Int. J. Wildland Fire 2001, 10, 373-380. [CrossRef] 
274. Andrews, P.L.; Loftsgaarden, D.O.; Bradshaw, L.S. Evaluation of fire danger rating indexes using logistic regression and percentile analysis. Int. J. Wildland Fire 2003, 12, 213-226. [CrossRef]

275. Andrews, P.L. Current status and future needs of the BehavePlus Fire Modeling System. Int. J. Wildland Fire 2014, 23, 21-33. [CrossRef]

276. Rorig, M.L.; Ferguson, S.A. Characteristics of lightning and wildland fire ignition in the Pacific Northwest. J. Appl. Meteorol. 1999, 38, 1565-1575. [CrossRef]

277. Larkin, N.K.; O’Neill, S.M.; Solomon, R.; Raffuse, S.; Strand, T.; Sullivan, D.C.; Krull, C.; Rorig, M.; Peterson, J.; Ferguson, S.A. The BlueSky Smoke modeling framework. Int. J. Wildland Fire 2009, 18, 906-920. [CrossRef] 